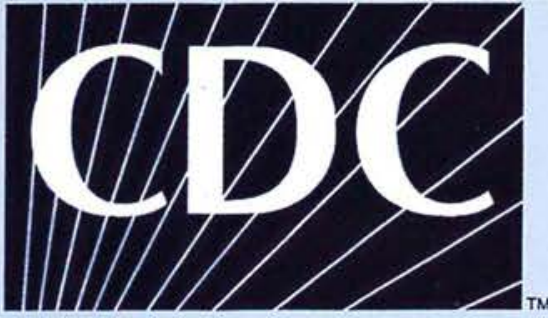

Workplace Safety and Health

\title{
Fatal Injuries to Civilian Workers in the United States, 1980-1995
}

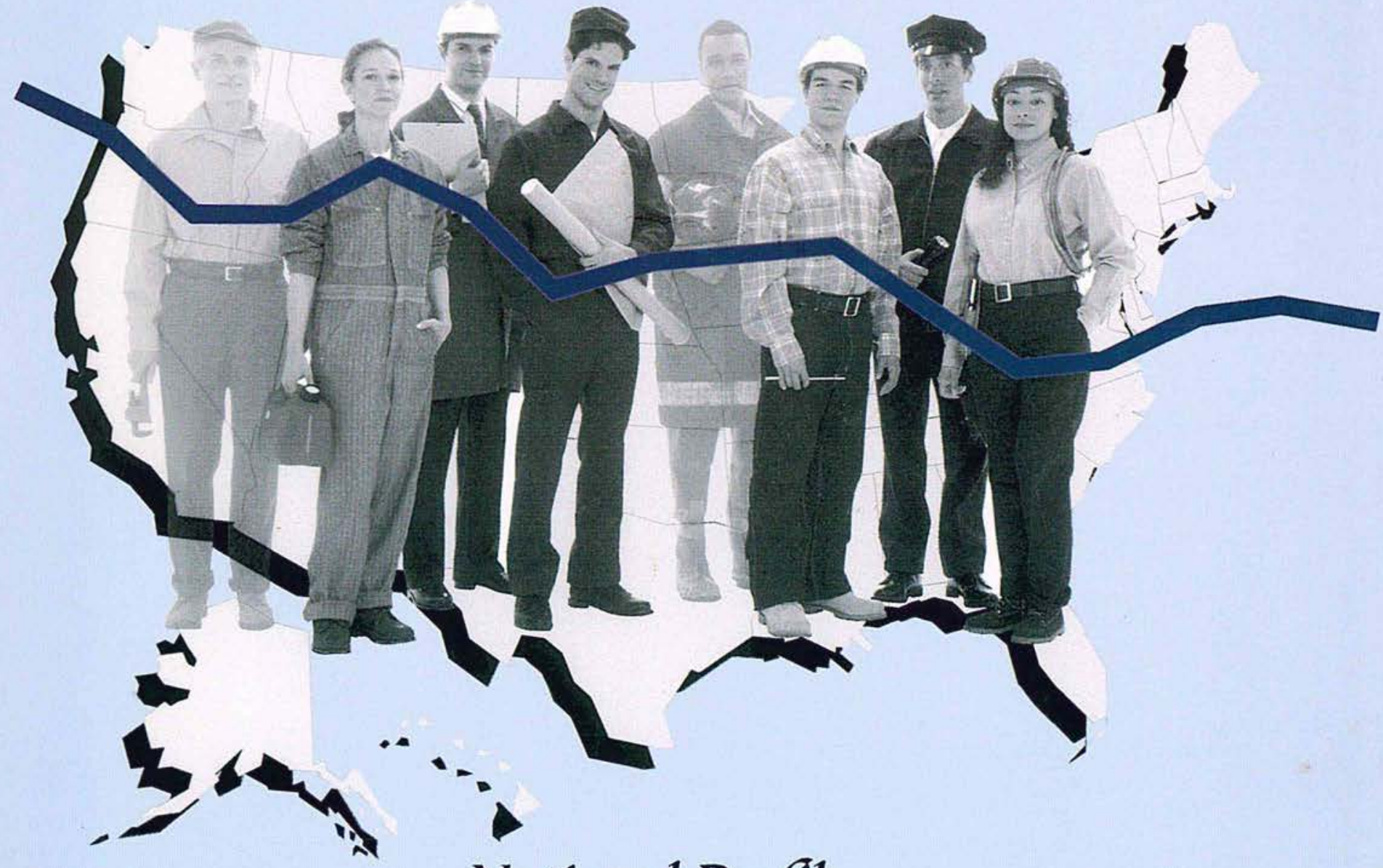

\section{National Profile}

Department of Health and Human Services Centers for Disease Control and Prevention 



\title{
Fatal Injuries to Civillian Workers in the United States, 1980-1995
}

\author{
(National Profile)
}

SuzanneM.Marsh

Larry A.Layne

DEPARTMENT OF HEALTH AND HUMAN SERVICES

Centers for Disease Control and Prevention

National Institute for Occupational Safety and Health

June 2001 


\title{
DISCLAIMER
}

Mention of the name of any company or product does not constitute endorsement by the National Institute for Occupational Safety and Health

This document is in the public domain and may be freely copied or reprinted.

Copies of this and other NIOSH documents are available from:

\author{
Publications Dissemination, EID \\ National Institute for Occupational Safety and Health \\ 4676 Columbia Parkway \\ Cincinnati, OH 45226-1998 \\ Fax number: (513) 533-8573 \\ Telephone number: 1-800-35-NIOSH (1-800-356-4674) \\ E-mail:pubstaft@cdc.gov \\ For further information about occupational safety and health \\ topics, call 1-800-35-NIOSH (1-800-356-4674), or \\ visit the NIOSH Web site at www.cdc.gov/niosh.
}

DHHS (NIOSH) PUBLICATION No. 2001-129 


\section{Foreword}

The Occupational Safety and Health Act of 1970 was enacted "to assure so far as possible every working man and woman in the Nation safe and healthful working conditions." However, deaths from injuries at work continue to be a major public health problem. On average, 16 workers die each day in this country. These workers die simply trying to earn a living. Through the National Traumatic Occupational Fatalities surveillance system, NIOSH continues to help fill the gap in the knowledge of traumatic work-related injury deaths.

This document provides an update to data published in the 1993 publication, Fatal Injuries to Workers in the United States, 1980-1989: A Decade of Surveillance. The current document includes 16 years of data from the National Traumatic Occupational Fatalities surveillance system for the years 1980 through 1995 . Occupational injury mortality statistics on over 93,000 deaths are provided by demographic and injury characteristics. These data illuminate the nature and magnitude of work-related injury death for the United States and comprise the most comprehensive summary available in one document.

Although fatal occupational injuries have decreased over the years, the burden remains high. The data presented in this report provide the basis for developing strategies to prevent traumatic workrelated injury deaths by profiling high-risk industries, occupations, and causes of fatal injuries. It is our hope that the information contained in this document will serve as a comprehensive resource for federal, state and local agencies, safety and health professionals, researchers, and others who can affect the prevention of occupational fatalities.

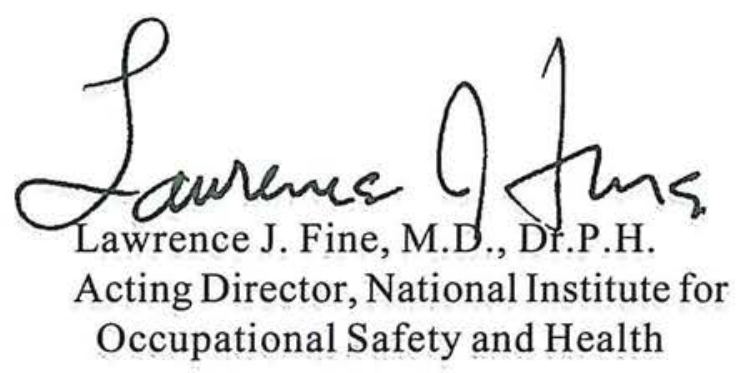





\section{Contents}

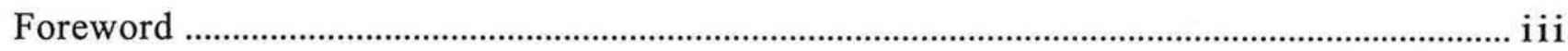

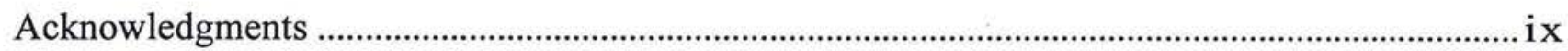

Public Health Summary .........................................................................................................

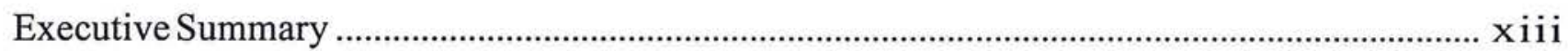

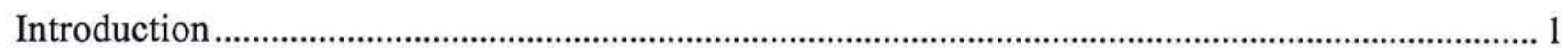

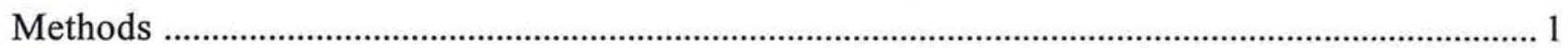

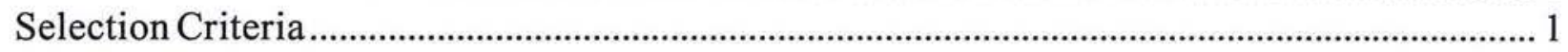

Why Death Certificates? ..................................................................................................... 2

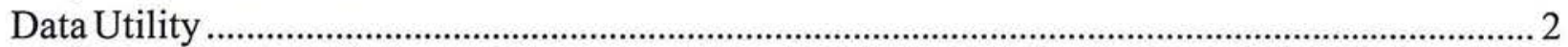

Data Coding: Industry/Occupation/Cause of Death ................................................................. 2

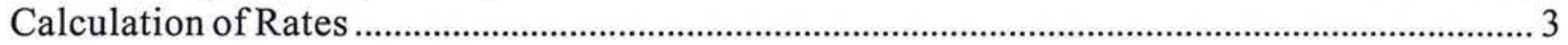

Limitations of Death Certificate Data.................................................................................... 4

Comparison of Data to Previously Published Fatal Occupational Injury Data ........................... 5

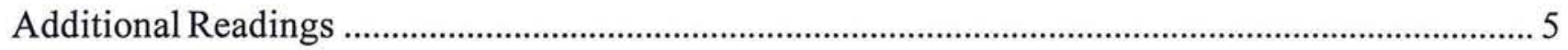

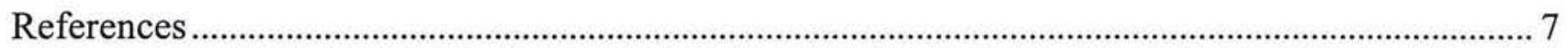

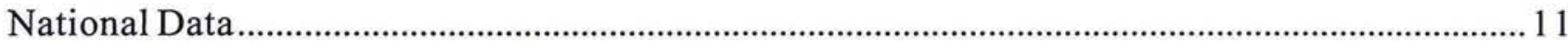

Table US-1. Number and Rate (per 100,000 workers) of Traumatic Occupational Fatalities by Year, US, 1980-1995 ……………….....................11

Table US-2. Number and Average Annual Rate (per 100,000 workers) of Traumatic Occupational Fatalities by State of Death, US, 1980-1995 ……….................12

Table US-3. Number and Average Annual Rate (per 100,000 workers) of Traumatic Occupational Fatalities by Sex, Race, and Age Group, US, 1980-1995 .......13

Table US-4. Number and Rate (per 100,000 workers) of Traumatic Occupational Fatalities for Sex, Race, and Age Group, by Year, US, 1980-1995 ................................... 14

Table US-5. Number and Average Annual Rate (per 100,000 workers) of Traumatic Occupational Fatalities for Race and Age Group, by Sex, US, 1980-1995 ........................ 15

Table US-6. Number and Average Annual Rate (per 100,000 workers) of Traumatic Occupational Fatalities by Age Group and Race, US, 1980-1995 ..................................... 15

Table US-7. Number and Average Annual Rate (per 100,000 workers) of Traumatic Occupational Fatalities by Cause of Death and Sex, US, 1980-1995

Table US-8. Number of Traumatic Occupational Fatalities by Cause of Death and Year, US, 1980-1995 


\section{Contents (continued)}

Table US-9. Rate (per 100,000 workers) of Traumatic Occupational Fatalities by Cause of Death and Year, US, 1980-1995

Table US-10. Number and Average Annual Rate (per 100,000 workers) of Traumatic

Occupational Fatalities by Cause of Death and Race, US, 1980-1995

Table US-11. Number of Traumatic Occupational Fatalities

by Cause of Death and Age Group, US, 1980-1995

Table US-12. Average Annual Rate (per 100,000 workers) of Traumatic

Occupational Fatalities by Cause of Death and Age Group, US, 1980-1995

Table US-13. Number and Average Annual Rate (per 100,000 workers) of Traumatic Occupational Fatalities by Industry Division, US, 1980-1995

Table US-14. Number and Rate (per 100,000 workers) of Traumatic Occupational

Fatalities by Industry Division and Year, US, 1980-1995

Table US-15. Number of Traumatic Occupational Fatalities

by Cause of Death and Industry Division, US, 1980-1995

Table US-16. Average Annual Rate (per 100,000 workers) of Traumatic Occupational

Fatalities by Cause of Death and Industry Division, US, 1980-1995

Table US-17. Number and Average Annual Rate (per 100,000 workers) of Traumatic

Occupational Fatalities by Industry Division and Age Group, US, 1983-1995....

Table US-18. Number and Average Annual Rate (per 100,000 workers) of Traumatic

Occupational Fatalities by Detailed Industry Groupings, US, 1983-1995

Table US-19. Number of Traumatic Occupational Fatalities

by Selected Detailed Industry Groupings and Year, US, 1983-1995

Table US-20. Rate (per 100,000 workers) of Traumatic Occupational Fatalities

by Selected Detailed Industry Groupings and Year, US, 1983-1995

Table US-21. Number of Traumatic Occupational Fatalities

by Selected Detailed Industry Groupings and Cause of Death, US, 1983-1995

Table US-22. Average Annual Rate (per 100,000 workers) of Traumatic Occupational

Fatalities by Selected Detailed Industry Groupings and Cause of Death, US, 1983-1995

Table US-23. Number and Average Annual Rate (per 100,000 workers) of Traumatic

Occupational Fatalities by Occupation Division, US, 1980-1995

Table US-24. Number and Rate (per 100,000 workers) of Traumatic Occupational

Fatalities by Occupation Division and Year, US, 1980-1995

Table US-25. Number of Traumatic Occupational Fatalities

by Cause of Death and Occupation Division, US, 1980-1995.

Table US-26. Average Annual Rate (per 100,000 workers) of Traumatic Occupational

Fatalities by Cause of Death and Occupation Division, US, 1980-1995 .34

Table US-27. Number and Average Annual Rate (per 100,000 workers) of Traumatic

Occupational Fatalities by Occupation Division and Age Group, US, 1983-1995 .35

Table US-28. Number and Average Annual Rate (per 100,000 workers) of Traumatic

Occupational Fatalities by Detailed Occupation Groupings, US, 1983-1995 36

Table US-29. Number and Rate (per 100,000 workers) of Traumatic Occupational

Fatalities by Selected Detailed Occupation Groupings and Year, US, 1983-1995 


\section{Contents (continued)}

Table US-30. Number and Average Annual Rate (per 100,000 workers) of Traumatic Occupational Fatalities by Selected Detailed Occupation Groupings and Cause of Death, US, 1983-1995

Table US-31. Number and Average Annual Rate (per 100,000 workers) of Traumatic

Occupational Fatalities by Industry and Occupation Division, US, 1983-1995

Appendix I: Abbreviations for Industry and Occupation Divisions

Appendix II: Detailed Bureau of the Census (BOC) Industry Groupings 43

Appendix III: Detailed Bureau of the Census (BOC) Occupation Groupings . 45

Appendix IV: ICD-9 E-code Rubrics for Cause of Death Categories 47

Appendix V: Operational Guidelines for Determination of Injury at Work

Appendix VI: Additional Readings 53 



\section{Acknowledgments}

The authors are indebted to Joyce R. Spiker of the Division of Safety Research for all of her efforts in preparing and formatting this document for publication.

The authors would also like to thank Susan P. Baker, M.P.H., Johns Hopkins Center for Injury Research and Policy; Lois A. Fingerhut, National Center for Health Statistics; James C. Helmkamp, Ph.D., West Virginia University Center for Rural Emergency Medicine; Edward L. Husting, Ph.D., National Center for Injury Prevention and Control; and John W. Ruser, Ph.D., Bureau of Labor Statistics for their helpful comments on this document.

The authors are also grateful to the State vital registrars and their staffs for providing these valuable data. The success of the National Traumatic Occupational Fatalities surveillance system is due to the help and cooperation of these State vital records offices. 



\section{Public Health Summary}

\section{What are the hazards?}

Over 93,000 workers were fatally injured while working in the United States from 1980 through 1995. Each day an average of 16 people died-simply by doing their jobs. These deaths result from exposure to many different hazards on the job. Leading causes of traumatic occupational fatalities include motor vehicles, homicides, machines, falls, electrocutions, and falling objects.

\section{How can a worker be exposed or put at risk?}

Workers are at risk of fatal injury in many different ways. Workers who operate motor vehicles or machines risk injury due to overturns or collisions. Taxicab drivers risk being killed during robbery attempts while construction workers risk fatal falls while working from heights. Electrical linemen risk electrocution while repairing power lines and loggers risk being struck by a falling tree during tree harvesting operations. These scenarios highlight some of the risks that are a daily presence in many of the industries and occupations in the United States. These jobs are frequently noted as being the jobs with the highest fatal injury rates. However, the potential for work-related injury exists in any job where injury risks are present and not controlled.

\section{What recommendations has the federal government made to protect workers' safety and health?}

Several federal agencies promulgate standards and regulations for worker safety. Agencies with specific regulatory authority for worker protection include the Occupational Safety and Health Administration, Federal Railroad Administration, Mine Safety and Health Administration, Federal Highway Administration, and the Employment Standards Administration. NIOSH, however, is the only federal agency responsible for conducting research and making recommendations for the prevention of work-related illnesses and injuries. NIOSH conducts research programs that improve understanding of injury and disease risks, identify populations at risk, and evaluate prevention strategies. For example, prevention recommendations are developed for specific risks through the Fatality Assessment and Control Evaluation program and the Health Hazard Evaluation program. Additional recommendations are developed through the funding of individual research projects, both within NIOSH and with extramural partners. As a result of these efforts NIOSH creates and disseminates scientifically valid recommendations for preventing work-related disease, injury, and disability.

\section{Where can more information be found?}

The references and additional readings contained in this document identify sources that provide additional information on fatal occupational injuries. Additional information on worker safety and health may be obtained from NIOSH through

$$
\begin{array}{|c|}
\begin{array}{c}
1-800-35-\mathrm{NIOSH} \\
(800-356-4674) \\
\text { or at }
\end{array} \\
\text { www.cdc.gov/niosh }
\end{array}
$$





\section{Executive Summary}

The National Institute for Occupational Safety and Health collects and automates death certificates from the 52 vital statistics reporting units in the 50 States, New York City, and the District of Columbia for workers 16 years of age or older who die as a result of a work-related injury. Analysis of occupational injury deaths, such as those gathered through the National Traumatic Occupational Fatalities (NTOF) surveillance system, facilitates identification of high risk worker groups and potential injury risk factors by demographic, employment, and injury characteristics. This promotes the effective use of resources aimed at preventing injuries in the workplace. In reviewing these data, it is important to note the distinction between the number of deaths and fatality rates. The number of deaths indicates the magnitude of a problem and fatality rates depict the risk faced by workers. Fatal occupational injury data for 1980 through 1995 are provided for the U.S. and for each State.

Major findings from this study:

- There were 93,338 civilian workers who died from injuries sustained while working in the U.S., 1980 through 1995 (Table US-1).

- The average annual occupational fatality rate for the U.S. civilian workforce was 5.2 per 100,000 workers for 1980 through 1995 (Table US-1).

- Civilian fatal occupational injuries decreased $28 \%$, from 7,343 fatalities in 1980 to 5,314 in 1995 (Table US-1).

- The average annual fatality rate per 100,000 civilian workers decreased, from 7.4 in 1980 to 4.3 in 1995 - a $42 \%$ decrease (Table US-1).

- The greatest number of fatal occupational injuries occurred in California $(9,670)$, Texas $(9,423)$, Florida $(5,596)$, Illinois $(4,169)$, and Pennsylvania $(3,926)$ (Table US-2).

- The States with the highest occupational injury fatality rates per 100,000 workers were Alaska (24.3), Wyoming (16.7), Montana (12.4), Idaho (10.7), West Virginia (10.4), and Mississippi (10.1) (Table US-2).

- The fatality rate for males (8.8 per 100,000 workers) was 11 times higher than the rate for females ( 0.8 per 100,000 workers) (Table US-3).

- Eighty-five percent of civilian workers who died were white and $11 \%$ were black (Table US-3).

- Black workers had the highest fatality rate per 100,000 workers (5.8), followed by whites (5.1) (Table US-3).

- The age group with the largest number of occupational injury fatalities was the 25-34 year old age group (26\%) followed closely by the $35-44$ year old age group (22\%) (Table US-3). 
- Workers 65 years and older had the highest fatality rate of all age groups (13.6 deaths per 100,000 workers) in every industry and occupation division (Tables US-3, US-17, US-27).

- The leading causes of occupational injury death in the U.S. were motor vehicle crashes $(23 \%)$, homicides (14\%), machine-related incidents (13\%), falls (10\%), electrocutions (7\%), and being struck by falling objects (6\%) (Table US-7).

- The highest rates by cause of death varied by gender: the highest rate for females was homicide ( 0.3 per 100,000 workers), while motor vehicle crashes (2.0 per 100,000 workers) were the cause of death with the highest rate among males (Table US-7).

- While the rate of motor vehicle-related fatalities decreased 36\% between 1980 and 1995 (from 1.7 per 100,000 workers to 1.1 ), motor vehicles continued to have the highest rate through 1995. Machines had the second highest rate per 100,000 workers until 1990, when they were surpassed by homicides (Table US-9).

- The highest rates by cause of death varied by race: the highest rate for whites was motor vehicle crashes (1.2 per 100,000 workers), while the highest rate by cause of death for blacks was homicide (1.4 per 100,000 workers) (Table US-10).

- The industry divisions with the greatest proportion of fatalities were construction (18\%), transportation/communication/public utilities (17\%), manufacturing (15\%), and agriculture/ forestry/fishing (12\%) (Table US-13).

- The mining industry had the highest average annual fatality rate per 100,000 workers (30.4), followed by agriculture/forestry/fishing (19.6), construction (15.3), and transportation/ communication/public utilities (12.6) (Table US-13).

- The highest rates by cause of death varied by industry: the highest rate in the agriculture/ forestry/fishing industry was for machinery-related incidents (6.6 per 100,000 workers), while the highest rate by cause of death in the retail trade industry was for homicides (1.7) (Table US-16).

- The occupation divisions with the greatest proportion of fatalities were precision production/ craft/repairers (21\%), transportation/material movers (17\%), farmers/foresters/fishers (13\%), and laborers (11\%) (Table US-23).

- The occupation division of farmers/foresters/fishers had the highest average annual fatality rate per 100,000 workers (21.9), followed by transportation/material movers (21.6), laborers (13.7), and precision production/craft/repairers (9.2) (Table US-23).

- The highest rates by cause of death varied by occupation: the highest rate among executives/ administrators/managers was for homicides ( 0.8 per 100,000 workers), while machineryrelated incident rates were highest among farmers/foresters/fishers (7.0) (Table US-26). 


\section{Fatal Injuries to Civillian Workers \\ in the United States, 1980-1995 \\ (National Profile)}

\section{Introduction}

The National Institute for Occupational Safety and Health (NIOSH) began collecting death certificates from all 50 States and the District of Columbia in answer to the need for a comprehensive enumeration of workers who sustain a fatal work-related injury. The National Traumatic Occupational Fatalities (NTOF) surveillance system was developed to fill gaps in the knowledge of work-related injury deaths in the United States (U.S.) by providing a census of occupational injury deaths for all U.S. workers.

Surveillance data such as those gathered through NTOF allow analysis of demographic, employment, and injury characteristics and also enable the examination of trends over time. These data allow the description of the nature and magnitude of the occupational injury problem in the U.S., the identification of potential risk factors, the generation of hypotheses for further research, and the setting of research and prevention priorities.

In 1993, a comprehensive summary of fatal occupational injuries in the U.S. was published based on data collected through NTOF for the years 1980 through 1989 (Jenkins et al., 1993). The present document extends the period of analysis to 16 years, providing the most comprehensive summary of fatal occupational injuries in one document for the U.S. as a whole, and for every State. This current document however, is considerably different than the earlier publication with the primary goal of providing detailed data in tabular format. The data are being presented in this format to provide the occupational safety and health community with direct access to data from the NTOF surveillance system. This document will serve as a comprehensive resource to describe the magnitude and circumstances of occupational injury deaths in the U.S. from 1980 through 1995.

\section{Methods}

\section{Selection Criteria}

The NTOF surveillance system is composed of information obtained from death certificates from the U.S. vital statistics reporting units in the 50 States, New York City, and the District of Columbia. For a case to be included in NTOF, it must meet three criteria:

1. the decedent is 16 years of age or older;

2. the external cause of death is classified as E800-E999 (International Classification of Diseases, Ninth Revision (World Health Organization, 1977)); and

3. the "Injury at Work?" item is marked positive by the certifier. 


\section{Why Death Certificates?}

While studies have shown that multiple source surveillance systems are the best approach in counting occupational fatalities, death certificates were chosen for NTOF because they are the single source that identifies the largest number of cases, and are fairly comparable between all vital statistics reporting units. Studies show that death certificates alone identify between $67 \%$ and $90 \%$ of all fatal work injuries among the various States (Baker et al., 1982; Karlson and Baker, 1978; Stout and Bell, 1991).

\section{Data Utility}

The NTOF system contains 30 variables useful for describing characteristics of victims as well as injury circumstances. Data elements include coded worker characteristics and injury circumstances such as sex, race, occupation, and cause of death. In addition, narrative text for industry, occupation, causes of death, and injury description is entered and maintained. Narrative data have been utilized in a number of focused analyses listed in the Additional Readings section of this document (Appendix VI).

\section{Data Coding: Industry/Occupation/Cause of Death}

Codes for 'usual' industry and occupation were assigned based on the narrative information contained on the death certificates. Two methods of coding were used for the periods 1980 through 1989 , and 1990 through 1995. Prior to the availability of an automated coding system, narrative information from the occupation and industry items was manually hand-coded by an expert coder, starting with data year 1990. Earlier years of data had been coded using a crude software program with known problems. The Standardized Occupation and Industry Coding (SOIC) software, ${ }^{1}$ a more sophisticated and accurate application released in 1998, was used to recode the data from 1980 through 1989 . Cases that could not be assigned a code by the SOIC software were manually hand-coded if the death certificate contained adequate information. The industry and occupation narratives were coded according to the 1980 and 1990 Bureau of the Census classification schemes (Bureau of Census, 1982; Bureau of Census, 1992). Death certificates for which no occupation or industry entry was present or for which the entry was too vague were coded into the "not classified" category. Certificates which had entries such as "housewife" or "student" were also coded into the "not classified" category. Appendix I provides explanations of the abbreviations used in the tables for occupation and industry divisions. Appendices II and III provide codes for detailed industry and occupation groupings included in the tables.

Cause of death codes are based on the International Classification of Diseases, Ninth Revision (ICD-9) supplementary chapter for the classification of external causes of injury and poisoning (World Health Organization, 1977) as assigned by trained nosologists and compiled by the National Center for Health Statistics (NCHS) for the Vital Statistics Mortality data (National Center for Health Statistics, 1980-1995). Codes from this chapter, denoted with a preceding "E," cover the spectrum of unintentional and intentional causes of death, with the actual E-code rubrics of the aggregated categories shown in Appendix IV. E-codes in this report were aggregated in a manner

\footnotetext{
${ }^{1}$ The Standardized Occupation and Industry Coding (SOIC) System is a software application developed collaboratively by NIOSH and other agencies and organizations. The software system takes real-world literal descriptions of occupations and industries from death certificates and other documents, and translates them into the 1990 Bureau of the Census occupation and industry codes. Based on a comparison of cases that were coded both by the SOIC software and by hand, it was determined that $87 \%$ of the cases matched for both industry and occupation.
} 
believed to be most beneficial for demonstrating exposures specific to traumatic occupational death. Alternative methods for grouping E-codes have been proposed, including the use of a matrix to present mechanism of injury within the major intent categories of unintentional, intentional, and selfinflicted (Centers for Disease Control and Prevention, 1997). While our rubric does not directly match the intent categories laid out in the suggested matrix framework, the authors believe the categories presented in this report are more beneficial for occupational death analysis and provide for continuity of earlier research. A footnote on Table US-8 provides information that may be used to calculate totals based on major intent categories.

\section{Calculation of Rates}

For this analysis, death certificates identified for inclusion in the NTOF data represent a complete count of traumatic occupational fatalities. These data therefore are not subject to sampling error, though they are subject to measurement error such as misclassification or failure to identify positive cases. The tables in this document include cells with counts of three or more deaths. Additionally, data for "Unknown" or "Not Classified" categories are only included for univariate tabulations.

Employment estimates for rate calculations were obtained from the Bureau of Labor Statistics' (BLS) Current Population Survey (CPS), a population-based household sample survey of the civilian noninstitutionalized population. These data were extracted from the BLS Employment and Earnings and the CPS monthly micro data files (Bureau of Labor Statistics, 1981-1996; Bureau of Labor Statistics, 1992). Because the employment data are based on a sample survey, standard errors are associated with the workforce estimates. However, confidence intervals for fatality rates were not calculated for this publication but are addressed elsewhere. ${ }^{1}$

Fatality rates were calculated as deaths per 100,000 workers. Rates were not calculated for categories with less than three fatalities or less than 20,000 employees, due to the instability of rates based on small numbers. In addition to this safeguard, considerable caution should be exercised in the interpretation of rates based on less than 20 deaths due to the possibility of rate instability (National Center for Health Statistics, 1999). It should be noted that in some instances rates were calculated for 1983 through 1995 only (e.g., industry division by occupation division), due to the lack of comparably coded denominator data for the earlier period.

The employment data used for rate calculations were based on the number of workers, rather than hours of work (or full-time equivalents). Using the number of workers does not account for the difference in exposure for groups that commonly work less than a full-time schedule of 40 hours per week (e.g., youth and older workers). For most workers however, the injury rates are similar regardless of which type of employment measure is used (Ruser, 1998). In addition, crude rates are presented in this report rather than age-adjusted rates. Age adjustments made when calculating occupational injury death rates, in nearly all cases, have only a negligible effect as age is not the primary risk factor (Bailer et al., 1998). Lastly, there is a dissimilarity between death and employment data when State-specific rates are calculated. The death data indicate the State where the death occurred while the employment data indicate the State of residence. This should be kept in mind when reviewing State fatality rates as net commuter in- and outflows may artificially increase or decrease State-specific rates.

'Standard errors associated with the CPS are explained in BLS' "Employment and Earnings" and "Geographic Profiles of Employment and Unemployment" (Bureau of Labor Statistics, 1981-1996; Bureau of Labor Statistics, 1982-1997). 


\section{Limitations of Death Certificate Data}

Limitations of death certificates used to ascertain work-related fatality information have previously been described (Bell et al., 1990; Jenkins et al., 1993; Russell and Conroy, 1991; Stout and Bell, 1991). Incomplete or unclear information on the death certificate and the lack of a national standard for the completion of the "Injury at Work?" item on the death certificate during this period are particular problems. Motor vehicle crashes and homicides accentuate the difficulty of attempting to identify occupational injuries (Colorado Dept. of Health, 1988; Russell and Conroy, 1991). Furthermore, because death certificates ask if the injury occurred at work, the death certificate may not be a true measure of work-relatedness for certain causes of death. For instance, a suicide that takes place at work may or may not be associated with work per se.

Standardized guidelines for coding the "Injury at Work?" item on the death certificates were not introduced until 1992. 'Certifier interpretation without the aid of standardized guidelines probably accentuated the problem of false positives being included in the data and false negatives not being identified. The improvements in the quality of the data, such as the sensitivity and positive predictive value, that resulted from these guidelines are unknown.

There are potential discrepancies in the collection of race and ethnicity in death data. ${ }^{2}$ NCHS made the first official recommendation to the States to include separate questions for race and ethnicity on their respective death certificates in January 1987 (Tolson et al., 1991). Variation in the collection methods employed by States is possible prior to the implementation of this recommendation. Additionally, studies have shown that race and ethnicity can be confused, and the manner in which the information is gathered affects the subsequent estimates (Tucker and Kojetin, 1996; Bureau of Census, 1996; Bureau of Census, 1997). As a result of the different approaches to collecting "race" and "ethnicity" information, rates should be interpreted with caution (Hahn, 1992).

Death certificates query for the "usual" occupation and industry of the decedent. Studies comparing the reliability of "usual" occupation and industry reported on death certificates to information derived from personal interviews prior to death reported agreement for "usual" occupation to be $48 \%$ to $76 \%$, and $57 \%$ to $76 \%$ for "usual" industry (Gute and Fulton, 1985; Schade and Swanson, 1988; Schumacher, 1986; Swanson et al., 1984; Turner et al., 1987). Studies comparing death certificate entries for usual occupation and industry to employment information at the time of death reported agreement for occupation to be $64 \%$ to $74 \%$, and $60 \%$ to $76 \%$ for industry (Davis, 1988 ; Illis et al., 1987; Schade and Swanson, 1988). Additionally, "most recent" occupation and industry were incorrectly entered in the "usual" occupation and industry fields on death certificates in about $6 \%$ to $11 \%$ of the cases (Davis, 1988; Schade and Swanson, 1988). For these reasons, there exists the possibility that for any surveillance system based on death certificates, cases may be misclassified with respect to industry and occupation.

\footnotetext{
'In 1992, national guidelines for completing the "Injury at Work?" item were developed and disseminated by the Association for Vital Records and Health Statistics (now the National Association for Public Health Statistics and Information Systems), NIOSH, NCHS, and the National Center for Environmental Health (Appendix V).

${ }^{2}$ During the period from 1980 through 1995, categories for race and ethnicity were defined by the Office of Management and Budget's Statistical Policy Directive 15. Racial and ethnic categories are not to be interpreted as biological or genetic, but are simply a social-political construct designed for collecting data. Race categories include: White, Black, Native American, and Asian/Pacific Islander. Ethnicity categories are: "Hispanic or Latino" and "Not Hispanic or Latino" (Office of Management and Budget, 1977).
} 
Finally, this report only includes information on deaths of civilians who died at work in the U.S. Civilians who died at work while abroad, and military personnel, regardless of their duty station, are excluded. The number of U.S. civilian workers killed while abroad is not known. And while NTOF does contain military cases for those who died at work in the U.S., they were excluded from this report primarily because of difficulties in establishing a definition of work-relatedness comparable to that of civilians. Unlike civilians, whose death is generally considered work-related if the incident occurred (1) on an employer's premise, or (2) off the worksite premises but while the worker was conducting legitimate work duties, active duty military personnel are considered to be on-duty 24 hours per day (Helmkamp and Kennedy, 1996).

\section{Comparison of Data to Previously Published Fatal Occupational Injury Data}

The data contained in the current publication are comparable to those from the 1993 document with a few exceptions. In the current report, the industry and occupation narrative data from 1980 through 1989 were recoded, thus frequency counts and rates for these two variables may differ from what was published in the earlier document. Additionally, rates by industry, overall rates by state, and industry rates by state were calculated based on a different source of employment data. The fatality rates by industry, overall rates by state, and industry rates by state included in the earlier publication were calculated using County Business Patterns (CBP), an establishment-based census of employers, supplemented with data from the 1982 Agricultural Census and data for the public administration industry from the CPS. The CBP excludes agricultural production workers, domestic-service workers, railroad workers subject to the Railroad Retirement Act, most government workers, and the self-employed. These exclusions introduce a bias in the calculation of industryspecific incidence rates, resulting in artificially high rates. Because the CPS, which is a populationbased survey, includes wage and salaried, self-employed, and all agricultural workers, it best matches the worker population included in NTOF. These differences are discussed in more detail elsewhere (Biddle and Kisner, 1998).

To address some of the limitations of death certificates and other existing data sources in the surveillance of fatal occupational injuries, in 1992 the BLS began collecting national work-related death data through the Census of Fatal Occupational Injuries (CFOI) system. The CFOI requirement that work-relatedness be substantiated by at least two sources has led to improvements in both the number of cases identified and the overall data accuracy. While CFOI and NTOF identified similar patterns from 1992 through 1995, NTOF captured 21,038 cases for this period compared to the 25,455 cases captured by CFOI (Toscano and Windau, 1998). Another difference between the two surveillance systems is that the coding systems used to specify cause of death differ. NTOF uses E-codes from the ICD-9 (World Health Organization, 1977) and CFOI uses the BLSdesigned Occupational Injury and Illness Classification System (Toscano et al., 1996). Direct comparisons of the two systems are complicated, but broad results for cause of death are similar.

\section{Additional Readings}

The last section in this document (Appendix VI) includes a list of articles and other publications that can be referred to for additional information. While not exhaustive, this list includes journal articles, NIOSH publications, and other articles that involved NTOF analyses. 



\section{References}

Bailer AJ, Stayner LT, Stout NA, Reed LD, Gilbert SJ [1998]. Trends in rates of occupational fatal injuries in the United States (1983-92). Occup Environ Med 55:485-489.

Baker SP, Samkoff JS, Fisher RS, VanBuren CB [1982]. Fatal occupational injuries. JAMA 248: 692-697.

Bell CA, Stout NA, Bender TR, Conroy CS, Crouse WE, Myers JR [1990]. Fatal occupational injuries in the United States, 1980 through 1985. JAMA 236:3047-3050.

Biddle EA, Kisner SM [1998]. Denominator effects on traumatic occupational fatality incidence rates. MetLife Statistical Bulletin 79:28-36.

Bureau of Census [1982]. 1980 census of population: alphabetic index of industries and occupations. Publication PHC80-R3. Washington, DC: US Department of Commerce, Bureau of Census.

Bureau of Census [1992]. 1990 census of population and housing: alphabetic index of industries and occupations. Publication CPH-R-4. Washington, DC: US Department of Commerce, Bureau of Census.

Bureau of Census [1996]. Findings on questions on race and hispanic origin tested in the 1996 national content survey. Population Division Working Paper No. 16. Washington, DC: US Department of Commerce, Bureau of Census.

Bureau of Census [1997]. Results of the 1996 race and ethnic targeted test. Population Division Working Paper No. 18. Washington, DC: US Department of Commerce, Bureau of Census.

Bureau of Labor Statistics [1981-1996]. Household data annual averages. Employment and earnings. Publications 28-40 (issue no. 1 for each year). Washington, DC: US Department of Labor, Bureau of Labor Statistics.

Bureau of Labor Statistics [1982-1997]. Geographic profile of employment and unemployment. Washington, DC: US Department of Labor, Bureau of Labor Statistics.

Bureau of Labor Statistics [1992 ]. Labor force, employment, and unemployment from the current population survey. In: BLS Handbook of Methods. Washington, DC: US Department of Labor, Bureau of Labor Statistics, pp. 3-12.

Centers for Disease Control and Prevention [1997]. Recommended framework for presenting injury mortality data. MMWR 46 (RR14):1-30.

Colorado Department of Health [1988]. Colorado population-based occupational injury and fatality surveillance system report, 1982-1984. Denver: Health Statistics Section, Colorado Department of Health. 
Davis H [1988]. The accuracy of industry data from death certificates for workplace homicide victims. Am J Public Health 78: 1579-1581.

Gute DM, Fulton JP [1985]. Agreement of occupation and industry data on Rhode Island death certificates with two alternative sources of information. Pub Hlth Reports 100(1): 66-72.

Hahn RA [1992]. The state of federal health statistics on racial and ethnic groups. JAMA 267:268271.

Helmkamp JC, Kennedy RD [1996]. National mortality profile of active duty personnel in the U.S. armed forces: 1980-1993. (DHHS [NIOSH] Pub No. 96-103). Morgantown, WV: National Institute for Occupational Safety and Health.

Illis WR, Swanson GM, Satariano ER, Schwartz AG [1987]. Summary measures of occupational history. Am J Public Health 77: 1532-1534.

Jenkins EL, Kisner SM, Fosbroke DE, Layne LA, Stout NA, Castillo DN, Cutlip PM, Cianfrocco $\mathrm{R}$ [1993]. Fatal injuries to workers in the United States, 1980-1989: A decade of surveillance National and state profiles. (DHHS [NIOSH] Pub No. 93-108S). Morgantown, WV: National Institute for Occupational Safety and Health.

Karlson TA, Baker SP [1978]. Fatal occupational injuries associated with motor vehicles. In: Proceedings of the 22nd Conference of the American Association for Automotive Medicine, Vol. 1. Arlington Heights, IL: American Association for Automotive Medicine: pp. 229-241.

National Center for Health Statistics [1999]. Vital statistics of United States: Mortality, 1995 Technical Appendix . Centers for Disease Control and Prevention: National Center for Health Statistics.

National Center for Health Statistics [1980-1995]. Vital statistics mortality public use data. Centers for Disease Control and Prevention: National Center for Health Statistics.

Office of Management and Budget [1977]. Race and ethnic standards for federal statistics and administrative reporting. Statistical Policy Directive No. 15. Washington, DC: Office of Management and Budget.

Ruser JW [1998]. Denominator choice in the calculation of workplace fatality rates. In: Fatal Workplace Injuries in 1996: A Collection of Data and Analysis. Report 922. Washington, DC: US Department of Labor, Bureau of Labor Statistics.

Russell J, Conroy C [1991]. Representativeness of deaths identified through the injury-at-work item on the death certificate: implications for surveillance. Am J Public Health 81: 1613-1618.

Schade WJ, Swanson GM [1988]. Comparison of death certificate occupation and industry data with life-time occupational histories obtained by interview. Am J Ind Med 14: 121-136. 
Schumacher MC [1986]. Comparison of occupation and industry information from death certificates and interviews. Am J Pub Hlth 76(6): 635-637.

Stout NA, Bell CA [1991]. Effectiveness of source documents for identifying fatal occupational injuries: a synthesis of studies. Am J Public Health 81: 725-728.

Swanson GM, Schwartz AG, Burrows RW [1984]. An assessment of occupation and industry data from death certificates and hospital medical records for population-based cancer surveillance. Am J Pub Hlth 74(5): 464-467.

Tolson GC, Barnes JM, Hay GA, Kowaleski JL [1991]. The 1989 revision of the U.S. standard certificates and reports. Vital Health Stat 4(28). Washington, DC: US Department of Health and Human Services, National Center for Health Statistics.

Toscano G, Windau J [1998]. Profile of fatal work injuries in 1996. In: Fatal Workplace Injuries in 1996: A Collection of Data and Analysis. Report 922. Washington, DC: US Department of Labor, Bureau of Labor Statistics

Toscano G, Windau J, Drudi D [1996]. Using the BLS occupational injury and illness classification system as a safety and health management tool. In: Fatal Workplace Injuries in 1994: A Collection of Data and Analysis. Report 908. Washington, DC: US Department of Labor, Bureau of Labor Statistics.

Tucker GC, Kojetin B [1996]. Testing racial and ethnic origin questions in the CPS supplement. In: Monthly Labor Review, September 1996. Washington, DC: US Department of Labor, Bureau of Labor Statistics.

Turner DW, Schumacher MC, West DW [1987]. Comparison of occupational interview data to death certificate data in Utah. Am J Ind Med 12: 145-151.

World Health Organization [1977]. International classification of diseases: manual on the international statistical classification of diseases, injuries, and causes of death. 9th Rev. Geneva, Switzerland. 



\section{National Data}

Table US-1. Number and Rate (per 100,000 workers) of Traumatic Occupational Fatalities by Year, US, 1980-1995.

\begin{tabular}{|c|c|c|}
\hline $\begin{array}{c}\text { YEAR OF } \\
\text { DEATH }\end{array}$ & $\begin{array}{c}\text { NUMBER OF } \\
\text { DEATHS }\end{array}$ & $\begin{array}{c}\text { RATE PER } \\
\mathbf{1 0 0 , 0 0 0}\end{array}$ \\
\hline \hline 1980 & 7,343 & 7.4 \\
\hline 1981 & 7,061 & 7.0 \\
\hline 1982 & 6,378 & 6.4 \\
\hline 1983 & 5,784 & 5.7 \\
\hline 1984 & 6,113 & 5.8 \\
\hline 1985 & 6,192 & 5.8 \\
\hline 1986 & 5,624 & 5.1 \\
\hline 1987 & 5,813 & 5.2 \\
\hline 1988 & 5,710 & 5.0 \\
\hline 1989 & 5,679 & 4.8 \\
\hline 1990 & 5,384 & 4.6 \\
\hline 1991 & 5,219 & 4.5 \\
\hline 1992 & 5,032 & 4.3 \\
\hline 1993 & 5,286 & 4.4 \\
\hline 1994 & 5,406 & 4.4 \\
\hline 1995 & 5,314 & 4.3 \\
\hline \hline Total & 93,338 & $\mathbf{5 . 2}$ \\
\hline
\end{tabular}


Table US-2. Number and Average Annual Rate (per 100,000 workers) of Traumatic Occupational Fatalities by State of Death, US, 1980-1995.

\begin{tabular}{|l|c|c|}
\hline \multicolumn{1}{|c|}{ STATE } & $\begin{array}{c}\text { NO. OF } \\
\text { DEATHS }\end{array}$ & $\begin{array}{c}\text { RATE PER } \\
\mathbf{1 0 0 , 0 0 0}\end{array}$ \\
\hline \hline Alabama & 1,864 & 6.8 \\
\hline Alaska & 897 & 24.3 \\
\hline Arizona & 590 & 2.4 \\
\hline Arkansas & 1,335 & 8.2 \\
\hline California & 9,670 & 4.7 \\
\hline Colorado & 1,631 & 6.2 \\
\hline Connecticut & 445 & 1.7 \\
\hline Delaware & 203 & 4.0 \\
\hline Dist Columbia & 296 & 6.3 \\
\hline Florida & 5,596 & 6.5 \\
\hline Georgia & 3,253 & 7.1 \\
\hline Hawaii & 348 & 4.4 \\
\hline Idaho & 784 & 10.7 \\
\hline Illinois & 4,169 & 4.9 \\
\hline Indiana & 2,284 & 5.5 \\
\hline lowa & 1,373 & 6.2 \\
\hline Kansas & 1,177 & 6.1 \\
\hline Kentucky & 2,037 & 8.0 \\
\hline Louisiana & 2,288 & 8.3 \\
\hline Maine & 404 & 4.6 \\
\hline Maryland & 1,213 & 3.3 \\
\hline Massachusetts & 990 & 2.1 \\
\hline Michigan & 2,433 & 3.7 \\
\hline Minnesota & 1,093 & 3.1 \\
\hline Mississippi & 1,683 & 10.1 \\
\hline Missouri & 1,815 & 4.8 \\
\hline
\end{tabular}

\begin{tabular}{|l|c|c|}
\hline \multicolumn{1}{|c|}{ STATE } & $\begin{array}{c}\text { NO. OF } \\
\text { DEATHS }\end{array}$ & $\begin{array}{c}\text { RATE PER } \\
\mathbf{1 0 0 , 0 0 0}\end{array}$ \\
\hline \hline Montana & 750 & 12.4 \\
\hline Nebraska & 1,004 & 8.0 \\
\hline Nevada & 678 & 7.7 \\
\hline New Hampshire & 256 & 3.0 \\
\hline New Jersey & 1,523 & 2.6 \\
\hline New Mexico & 755 & 7.5 \\
\hline New York & 3,567 & 2.8 \\
\hline North Carolina & 2,657 & 5.4 \\
\hline North Dakota & 441 & 8.9 \\
\hline Ohio & 2,662 & 3.4 \\
\hline Oklahoma & 1,328 & 5.8 \\
\hline Oregon & 1,546 & 7.3 \\
\hline Pennsylvania & 3,926 & 4.7 \\
\hline Rhode Island & 194 & 2.6 \\
\hline South Carolina & 1,408 & 5.8 \\
\hline South Dakota & 495 & 9.2 \\
\hline Tennessee & 1,970 & 5.7 \\
\hline Texas & 9,423 & 7.7 \\
\hline Utah & 926 & 7.8 \\
\hline Vermont & 194 & 4.4 \\
\hline Virginia & 2,495 & 5.4 \\
\hline Washington & 1,783 & 5.2 \\
\hline West Virginia & 1,142 & 10.4 \\
\hline Wisconsin & 1,729 & 4.5 \\
\hline Wyoming & 615 & 16.7 \\
\hline
\end{tabular}


Table US-3. Number and Average Annual Rate* (per 100,000 workers) of Traumatic Occupational Fatalities by Sex, Race, and Age Group, US, 1980-1995.

\begin{tabular}{|c|c|c|}
\hline DEMOGRAPHICS & $\begin{array}{c}\text { NUMBER OF } \\
\text { DEATHS }\end{array}$ & $\begin{array}{c}\text { RATE PER } \\
\mathbf{1 0 0 , 0 0 0}\end{array}$ \\
\hline \hline Sex & & \\
\hline Male & 87,254 & 8.8 \\
\hline Female & 6,078 & 0.8 \\
\hline Unknown & 6 & - \\
\hline Race & & \\
\hline White & 79,487 & 5.1 \\
\hline Black & 10,273 & 5.8 \\
\hline Other & 2,693 & 4.9 \\
\hline Unknown & 885 & - \\
\hline Age Group & & \\
\hline $16-17$ & 892 & 2.2 \\
\hline $18-19$ & 2,508 & 3.9 \\
\hline $20-24$ & 10,012 & 4.7 \\
\hline $25-34$ & 24,109 & 4.8 \\
\hline $35-44$ & 20,184 & 4.6 \\
\hline $45-54$ & 15,983 & 5.3 \\
\hline $55-64$ & 12,633 & 7.0 \\
\hline $65+$ & 6,922 & 13.6 \\
\hline Unknown & 95 & - \\
\hline
\end{tabular}

- Rates not calculated for "unknown" or "not classified" categories. 
Table US-4. Number ${ }^{*}$ and Rate (per 100,000 workers) of Traumatic Occupational Fatalities for Sex, Race, and Age Group, by Year, US, 1980-1995.

\begin{tabular}{|c|c|c|c|c|c|c|c|c|c|c|c|c|c|c|c|c|c|}
\hline \multirow{2}{*}{\multicolumn{2}{|c|}{ DEMOGRAPHICS }} & \multicolumn{16}{|c|}{ YEAR OF DEATH } \\
\hline & & \multirow[t]{2}{*}{1980} & \multirow[t]{2}{*}{1981} & \multirow{2}{*}{1982} & \multirow[t]{2}{*}{1983} & \multirow[t]{2}{*}{1984} & \multirow[t]{2}{*}{\begin{tabular}{|l|}
1985 \\
\end{tabular}} & \multirow[t]{2}{*}{1986} & \multirow[t]{2}{*}{1987} & \multirow{2}{*}{1988} & \multirow{2}{*}{1989} & \multirow{2}{*}{1990} & \multirow{2}{*}{1991} & \multirow{2}{*}{1992} & \multirow[t]{2}{*}{1993} & \multirow{2}{*}{1994} & \multirow[t]{2}{*}{1995} \\
\hline Sex & & & & & & & & & & & & & & & & & \\
\hline \multirow{2}{*}{ Male } & & 914 & 677 & 6,007 & 5,461 & 5,758 & 5,807 & 5,258 & 5,428 & 5,334 & 5,285 & 5,035 & 4,836 & 4,688 & 4,908 & 4,970 & 4,888 \\
\hline & 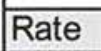 & 2.3 & 11.6 & 10.7 & 9.6 & 9.7 & 9.7 & 8.6 & 8.7 & 8.4 & 8.2 & 7.8 & 7.6 & 7.3 & 7.5 & 7.5 & 7.3 \\
\hline \multirow{2}{*}{ Female } & & 29 & 384 & 371 & 323 & 355 & 385 & 366 & 385 & 376 & 394 & 349 & 381 & 343 & 378 & 433 & 426 \\
\hline & & 0 & 0.9 & 0.9 & 0.7 & 0.8 & 0.8 & 0.8 & 0.8 & 0.7 & 0.7 & 0.7 & 0.7 & 0.6 & 0.7 & 0.8 & 0.7 \\
\hline \multicolumn{18}{|l|}{ Race } \\
\hline \multirow{2}{*}{ White } & & 312 & 128 & 5,522 & 002 & 5,313 & 5,302 & 4,837 & 4,955 & 4,901 & 4,865 & 4,486 & 4,284 & 4,200 & 4,389 & 4,516 & $4,47 t$ \\
\hline & Rate & 7.3 & 6.9 & 6.3 & 5.6 & 5.8 & 5.7 & 5.1 & 5.1 & 4.9 & 4.8 & 4.4 & 4.2 & 4.1 & 4.3 & 4.3 & 4.2 \\
\hline \multirow{2}{*}{ Black } & No. & 841 & 739 & 661 & 594 & 629 & 689 & 614 & 689 & 585 & 644 & 611 & 616 & 531 & 591 & 628 & 611 \\
\hline & ate & 9.2 & 7.9 & 7.2 & 6.3 & 6.2 & 6.6 & 5.7 & 6.1 & 5.0 & 5.4 & 5.1 & 5.2 & 4.4 & 4.9 & 4.9 & 4.6 \\
\hline \multirow{2}{*}{ Othe } & No. & 126 & 141 & 137 & 139 & 138 & 167 & 123 & 145 & 142 & 147 & 147 & 203 & 222 & 266 & 252 & 198 \\
\hline & ate & 7.0 & 6.0 & 5.6 & 5.4 & 5.0 & 5.7 & 3.9 & 4.3 & 4.1 & 3.9 & 3.8 & 5.1 & 5.3 & 6.1 & 5.0 & 3.9 \\
\hline \multicolumn{18}{|c|}{ Age Group } \\
\hline & & 25 & 100 & 86 & 45 & 53 & 52 & 60 & 53 & 48 & 47 & 47 & 28 & 39 & 34 & 40 & 35 \\
\hline & $\bar{R}$ & 0 & .5 & 3.4 & 9 & 2.2 & 2. & 2.3 & 1.9 & 1. & 1.8 & 2.0 & 1.3 & 1.8 & 1.5 & 1.6 & 1.4 \\
\hline & & 20 & 267 & 207 & 204 & 180 & 155 & 171 & 146 & 141 & 123 & 137 & 101 & 80 & 86 & 89 & 101 \\
\hline & Rate & - & 6.1 & 5.1 & 5.0 & 4.4 & 3.9 & 4.4 & 3.7 & 3.4 & 2.9 & 3.3 & 2.7 & 2.3 & 2.4 & 2.4 & 2.6 \\
\hline & No. & 051 & 988 & 843 & 721 & 786 & 728 & 614 & 615 & 568 & 509 & 495 & 445 & 408 & 410 & 444 & 387 \\
\hline & Rate & 7.4 & 7.0 & 6.1 & 5.2 & 5.5 & 5.2 & 4.5 & 4.5 & 4.3 & 3.9 & 3.7 & 3.4 & 3.2 & 3.2 & 3.5 & 3.1 \\
\hline & No. & 1,842 & 1,896 & 1,641 & 1,472 & 1,644 & 1,682 & 1,519 & 1,550 & 1,550 & 1,561 & 1,403 & 1,332 & 1,241 & 1,294 & 1,296 & 1,186 \\
\hline & Rate & 6.8 & 6.7 & 5.8 & 5.1 & 5.4 & 5.4 & 4.7 & 4.7 & 4.6 & 4.6 & 4.1 & 4.0 & 3.8 & 4.0 & 4.0 & 3.7 \\
\hline & No. & 1,281 & 1,190 & 1,204 & 1,193 & 1,237 & 1,331 & 1,201 & 1,217 & 1,230 & 1,257 & 1,242 & 1,290 & 1,274 & 1,351 & 1,346 & 1,340 \\
\hline & Rate & 6.6 & 5.9 & 5.8 & 5.4 & 5.2 & 5.4 & 4.6 & 4.5 & 4.4 & 4.3 & 4.0 & 4.1 & 4.0 & 4.1 & 4.0 & 3.9 \\
\hline & No. & 1,176 & 1,178 & 1,068 & 939 & 971 & 939 & 917 & 913 & 939 & 970 & 942 & 926 & 945 & 1,001 & 1,055 & 1,104 \\
\hline & Rate & 7.2 & 7.2 & 6.7 & 5.9 & 6.0 & 5.7 & 5.4 & 5.2 & 5.1 & 5.0 & 4.8 & 4.7 & 4.5 & 4.5 & 4.5 & 4.5 \\
\hline & & 1,026 & 963 & 865 & 805 & 824 & 895 & 747 & 857 & 795 & 777 & 692 & 692 & 627 & 673 & 700 & 695 \\
\hline $55-64$ & |Rate & 8.8 & 8.4 & 7.6 & 7.1 & 7.2 & 7.8 & 6.5 & 7.5 & 7.0 & 6.8 & 6.2 & 6.3 & 5.7 & 6.1 & 6.2 & 6.1 \\
\hline & & 509 & 472 & 458 & 402 & 414 & 398 & 387 & 457 & 436 & 427 & 424 & 401 & 417 & 432 & 429 & 459 \\
\hline & Rate & 17.0 & 15.8 & 15.5 & 13.5 & 14.4 & 14.1 & 13.2 & 15.0 & 13.6 & 12.7 & 12.6 & 12.1 & 12.4 & 12.9 & 11.6 & 12.4 \\
\hline
\end{tabular}

"Numbers not reported for "unknown" or "not classified" categories. 
Table US-5. Number ${ }^{*}$ and Average Annual Rate (per 100,000 workers) of Traumatic Occupational Fatalities for Race and Age Group, by Sex, US, 1980-1995.

\begin{tabular}{|l|c|c|c|c|}
\hline \multirow{2}{*}{ DEMOGRAPHICS } & \multicolumn{4}{|c|}{ SEX } \\
\cline { 2 - 5 } & \multicolumn{2}{|c|}{ MALE } & \multicolumn{2}{c|}{ FEMALE } \\
\cline { 2 - 5 } & No. & Rate & No. & Rate \\
\hline \hline Race & & & & \\
\hline White & 74,446 & 8.6 & 5,037 & 0.7 \\
\hline Black & 9,521 & 10.7 & 752 & 0.8 \\
\hline Other & 2,446 & 7.8 & 245 & 0.9 \\
\hline Age Group & & & & \\
\hline $16-17$ & 814 & 3.8 & 78 & 0.4 \\
\hline $18-19$ & 2,321 & 7.1 & 186 & 0.6 \\
\hline $20-24$ & 9,262 & 8.2 & 750 & 0.7 \\
\hline $25-34$ & 22,439 & 8.0 & 1,668 & 0.8 \\
\hline $35-44$ & 18,869 & 7.9 & 1,313 & 0.7 \\
\hline $45-54$ & 15,012 & 9.0 & 970 & 0.7 \\
\hline $55-64$ & 11,966 & 11.4 & 667 & 0.9 \\
\hline $65+$ & 6,480 & 21.5 & 442 & 2.1 \\
\hline
\end{tabular}

Numbers not reported for "unknown" or "not classified" categories.

Table US-6. Number* and Average Annual Rate (per 100,000 workers) of Traumatic Occupational Fatalities by Age Group and Race, US, 1980-1995.

\begin{tabular}{|c|c|c|c|c|c|c|}
\hline \multirow{2}{*}{ AGE GRouP } & \multicolumn{6}{|c|}{ RACE } \\
\cline { 2 - 7 } & \multicolumn{2}{|c|}{ WHITE } & \multicolumn{2}{c|}{ BLACK } & \multicolumn{2}{c|}{ OTHER } \\
\cline { 2 - 7 } & No. & Rate & No. & Rate & No. & Rate \\
\hline \hline $16-17$ & 785 & 2.1 & 77 & 2.6 & 23 & 2.3 \\
\hline $18-19$ & 2,229 & 4.0 & 193 & 3.4 & 66 & 3.8 \\
\hline $20-24$ & 8,674 & 4.7 & 950 & 4.3 & 285 & 4.3 \\
\hline $25-34$ & 20,308 & 4.7 & 2,749 & 5.0 & 812 & 4.6 \\
\hline $35-44$ & 16,809 & 4.5 & 2,487 & 5.5 & 681 & 4.4 \\
\hline $45-54$ & 13,485 & 5.2 & 1,898 & 6.7 & 449 & 4.7 \\
\hline $55-64$ & 10,907 & 6.7 & 1,338 & 8.6 & 281 & 6.5 \\
\hline $65+$ & 6,234 & 13.5 & 560 & 14.6 & 90 & 9.5 \\
\hline
\end{tabular}

"Numbers not reported for "unknown" or "not classified" categories. 
Table US-7. Number and Average Annual Rate* (per 100,000 workers) of Traumatic Occupational Fatalities by Cause of Death and Sex, US, 1980-1995.

\begin{tabular}{|l|c|c|c|c|c|c|}
\hline \multirow{2}{*}{ CAUSE OF DEATH } & \multicolumn{2}{|c|}{ TOTAL } & \multicolumn{2}{c|}{ MALE } & \multicolumn{2}{c|}{ FEMALE } \\
\cline { 2 - 7 } & No. & Rate & No. & Rate & No. & Rate \\
\hline \hline Motor Vehicle & 21,715 & 1.2 & 20,175 & 2.0 & 1,539 & 0.2 \\
\hline Homicide & 12,863 & 0.7 & 10,302 & 1.0 & 2,560 & 0.3 \\
\hline Machine & 12,334 & 0.7 & 12,053 & 1.2 & 281 & $<0.1$ \\
\hline Fall & 9,070 & 0.5 & 8,760 & 0.9 & 308 & $<0.1$ \\
\hline Electrocution & 6,233 & 0.3 & 6,190 & 0.6 & 43 & $<0.1$ \\
\hline Struck by Falling Object & 5,984 & 0.3 & 5,917 & 0.6 & 67 & $<0.1$ \\
\hline Air Transport & 3,261 & 0.2 & 3,043 & 0.3 & 218 & $<0.1$ \\
\hline Suicide & 3,155 & 0.2 & 2,907 & 0.3 & 248 & $<0.1$ \\
\hline Nature/Environment & 2,394 & 0.1 & 2,280 & 0.2 & 114 & $<0.1$ \\
\hline Explosion & 2,344 & 0.1 & 2,254 & 0.2 & 90 & $<0.1$ \\
\hline Flying Object/Caught In & 2,172 & 0.1 & 2,130 & 0.2 & 42 & $<0.1$ \\
\hline Water Transport & 1,813 & 0.1 & 1,779 & 0.2 & 34 & $<0.1$ \\
\hline Suffocation & 1,715 & 0.1 & 1,674 & 0.2 & 41 & $<0.1$ \\
\hline Fire & 1,591 & 0.1 & 1,449 & 0.1 & 142 & $<0.1$ \\
\hline Poisoning & 1,455 & 0.1 & 1,389 & 0.1 & 66 & $<0.1$ \\
\hline Drowning & 1,358 & 0.1 & 1,292 & 0.1 & 66 & $<0.1$ \\
\hline Rail Transport & 661 & $<0.1$ & 650 & 0.1 & 11 & $<0.1$ \\
\hline Other & 2,622 & 0.1 & 2,461 & 0.2 & 159 & $<0.1$ \\
\hline Unknown/Undetermined & 598 & - & 549 & - & 49 & - \\
\hline
\end{tabular}

"Rates not calculated for "unknown" or "not classified" categories. 
Table US-8. Number" of Traumatic Occupational Fatalities by Cause of Death and Year, US, 1980-1995.

\begin{tabular}{|c|c|c|c|c|c|c|c|c|c|c|c|c|c|c|c|c|}
\hline \multirow{2}{*}{ CAUSE OF DEATH } & \multicolumn{16}{|c|}{ YEAR OF DEATH } \\
\hline & 1980 & 1981 & 1982 & 1983 & 1984 & 1985 & 1986 & 1987 & 1988 & 1989 & 1990 & 1991 & 1992 & 1993 & 1994 & 1995 \\
\hline Motor & 1,639 & 1,544 & 1,326 & 1,333 & 1,523 & 1,426 & 1,246 & 1,350 & 1,407 & 1,463 & 1,300 & 1,104 & 1,129 & 1,268 & 1,338 & $\overline{1,319}$ \\
\hline omicid & 913 & 935 & 854 & 719 & 657 & 750 & 681 & 674 & 714 & 696 & 735 & 901 & 888 & 951 & 928 & 867 \\
\hline Aachine & 79 & 1,025 & 956 & 798 & 815 & 837 & 772 & 26 & 739 & 745 & 699 & 678 & 664 & 623 & 580 & 598 \\
\hline Eall & 702 & 699 & 608 & 545 & 570 & 635 & 523 & 576 & 570 & 553 & 587 & 491 & 446 & 476 & 553 & 536 \\
\hline Elec & 75 & 509 & 498 & 439 & 484 & 399 & 440 & 06 & 381 & 329 & 320 & 311 & 270 & 274 & 294 & 304 \\
\hline Struck & 476 & 442 & 426 & 383 & 407 & 431 & 428 & 420 & 350 & 371 & 355 & 341 & 286 & 295 & 310 & 263 \\
\hline Air Tre & 283 & 262 & 251 & 199 & 236 & 232 & 201 & 224 & 163 & 191 & 141 & 162 & 180 & 188 & 179 & 169 \\
\hline Suicide & 151 & 164 & 197 & 167 & 182 & 223 & 189 & 242 & 212 & 206 & 185 & 198 & 197 & 208 & 205 & 229 \\
\hline Natur & 174 & 174 & 159 & 152 & 143 & 120 & 136 & 162 & 157 & 140 & 123 & 126 & 157 & 161 & 156 & 154 \\
\hline Expl & 201 & 254 & 162 & 166 & 159 & 199 & 134 & 111 & 133 & 159 & 143 & 112 & 105 & 102 & 99 & 105 \\
\hline Flying & 203 & 187 & 141 & 151 & 155 & 139 & 140 & 137 & 152 & 134 & 128 & 99 & 100 & 91 & 115 & 100 \\
\hline Water & 153 & 135 & 124 & 140 & 115 & 137 & 93 & 89 & 120 & 137 & 125 & 108 & 101 & 100 & 69 & 67 \\
\hline Suffocation & 149 & 140 & 131 & 100 & 115 & 134 & 118 & 122 & 110 & 86 & 101 & 75 & 79 & 81 & 82 & 92 \\
\hline Fire & 161 & 113 & 123 & 85 & 156 & 136 & 93 & 78 & 109 & 87 & 87 & 118 & 53 & 46 & 77 & 69 \\
\hline Poisoning & 119 & 121 & 92 & 80 & 110 & 101 & 84 & 89 & 97 & 111 & 77 & 61 & 80 & 74 & 90 & 69 \\
\hline Drowning & 109 & 88 & 98 & 99 & 102 & 76 & 77 & 86 & 66 & 93 & 77 & 96 & 66 & 82 & 79 & 64 \\
\hline Rail Trans & 74 & 43 & 46 & 45 & 45 & 34 & 44 & 56 & 35 & 45 & 29 & 29 & 25 & 46 & 36 & 29 \\
\hline Other $^{\dagger}$ & 226 & 159 & 129 & 143 & 115 & 164 & 151 & 140 & 167 & 107 & 137 & 179 & 181 & 190 & 190 & 244 \\
\hline
\end{tabular}

"Numbers not reported for "unknown" or "not classified" categories.

tFor the purpose of cross-classification, the "Other" category contains 47 cases coded as E970-E978 and 45 in E990-E999. 
Table US-9. Rate (per 100,000 workers) of Traumatic Occupational Fatalities by Cause of Death and Year, US, 1980-1995.

\begin{tabular}{|c|c|c|c|c|c|c|c|c|c|c|c|c|c|c|c|c|}
\hline \multirow{2}{*}{ CAUSE OF DEATH } & \multicolumn{16}{|c|}{ YEAR OF DEATH } \\
\hline & 1980 & 1981 & 1982 & 1983 & 1984 & 1985 & 1986 & 1987 & 1988 & 1989 & 1990 & 1991 & 1992 & 1993 & 1994 & 1995 \\
\hline Motor Veh & 1.7 & 1.5 & $1.3^{\circ}$ & 1.3 & 1.5 & 1.3 & 1.1 & 1.2 & 1.2 & 1.2 & 1.1 & 0.9 & 1.0 & 1.1 & 1.1 & 1.1 \\
\hline Homicide & 0.9 & 0.9 & 0.9 & 0.7 & 0.6 & 0.7 & 0.6 & 0.6 & 0.6 & 0.6 & 0.6 & 0.8 & 0.8 & 0.8 & 0.8 & 0.7 \\
\hline Machine & 1.0 & 1.0 & 1.0 & 0.8 & 0.8 & 0.8 & 0.7 & 0.7 & 0.6 & 0.6 & 0.6 & 0.6 & 0.6 & 0.5 & 0.5 & 0.5 \\
\hline Fall & 0.7 & 0.7 & 0.6 & 0.5 & 0.5 & 0.6 & 0.5 & 0.5 & 0.5 & 0.5 & 0.5 & 0.4 & 0.4 & 0.4 & 0.4 & 0.4 \\
\hline Electrocution & 0.6 & 0.5 & 0.5 & 0.4 & 0.5 & 0.4 & 0.4 & 0.4 & 0.3 & 0.3 & 0.3 & 0.3 & 0.2 & 0.2 & 0.2 & 0.2 \\
\hline Struck by Falli & 0.5 & 0.4 & 0.4 & 0.4 & 0.4 & 0.4 & 0.4 & 0.4 & 0.3 & 0.3 & 0.3 & 0.3 & 0.2 & 0.2 & 0.3 & 0.2 \\
\hline Air Transport & 0.3 & 0.3 & 0.3 & 0.2 & 0.2 & 0.2 & 0.2 & 0.2 & 0.1 & 0.2 & 0.1 & 0.1 & 0.2 & 0.2 & 0.1 & 0.1 \\
\hline Suicide & 0.2 & 0.2 & 0.2 & 0.2 & 0.2 & 0.2 & 0.2 & 0.2 & 0.2 & 0.2 & 0.2 & 0.2 & 0.2 & 0.2 & 0.2 & 0.2 \\
\hline Nature/Envi & 0.2 & 0.2 & 0.2 & 0.2 & 0.1 & 0.1 & 0.1 & 0.1 & 0.1 & 0.1 & 0.1 & 0.1 & 0.1 & 0.1 & 0.1 & 0.1 \\
\hline Explosion & 0.2 & 0.3 & 0.2 & 0.2 & 0.2 & 0.2 & 0.1 & 0.1 & 0.1 & 0.1 & 0.1 & 0.1 & 0.1 & 0.1 & 0.1 & 0.1 \\
\hline Flying Object/Cau & 0.2 & 0.2 & 0.1 & 0.1 & 0.1 & 0.1 & 0.1 & 0.1 & 0.1 & 0.1 & 0.1 & 0.1 & 0.1 & 0.1 & 0.1 & 0.1 \\
\hline Water Transport & 0.2 & 0.1 & 0.1 & 0.1 & 0.1 & 0.1 & 0.1 & 0.1 & 0.1 & 0.1 & 0.1 & 0.1 & 0.1 & 0.1 & 0.1 & 0.1 \\
\hline Suffocatic & 0.2 & 0.1 & 0.1 & 0.1 & 0.1 & 0.1 & 0.1 & 0.1 & 0.1 & 0.1 & 0.1 & 0.1 & 0.1 & 0.1 & 0.1 & 0.1 \\
\hline \begin{tabular}{|l|} 
Fire \\
\end{tabular} & 0.2 & 0.1 & 0.1 & 0.1 & 0.1 & 0.1 & 0.1 & 0.1 & 0.1 & 0.1 & 0.1 & 0.1 & $<0.1$ & $<0.1$ & 0.1 & 0.1 \\
\hline Poisoning & 0.1 & 0.1 & 0.1 & 0.1 & 0.1 & 0.1 & 0.1 & 0.1 & 0.1 & 0.1 & 0.1 & 0.1 & 0.1 & 0.1 & 0.1 & 0.1 \\
\hline Drowning & 0.1 & 0.1 & 0.1 & 0.1 & 0.1 & 0.1 & 0.1 & 0.1 & 0.1 & 0.1 & 0.1 & 0.1 & 0.1 & 0.1 & 0.1 & 0.1 \\
\hline Rail Transport & 0.1 & $<0.1$ & $<0.1$ & $<0.1$ & $<0.1$ & $<0.1$ & $<0.1$ & $<0.1$ & $<0.1$ & $<0.1$ & $<0.1$ & $<0.1$ & $<0.1$ & $<0.1$ & $<0.1$ & $<0.1$ \\
\hline Other & 0.2 & 0.2 & 0.1 & 0.1 & 0.1 & 0.2 & 0.1 & 0.1 & 0.1 & 0.1 & 0.1 & 0.2 & 0.2 & 0.2 & 0.2 & 0.2 \\
\hline
\end{tabular}


Table US-10. Number" and Average Annual Rate (per 100,000 workers) of Traumatic Occupational Fatalities by Cause of Death and Race, US, 1980-1995.

\begin{tabular}{|l|c|c|c|c|c|c|}
\hline \multirow{2}{*}{ CAUSE OF DEATH } & \multicolumn{6}{|c|}{ RACE } \\
\cline { 2 - 7 } & \multicolumn{2}{|c|}{ WHITE } & \multicolumn{2}{c|}{ BLACK } & \multicolumn{2}{c|}{ OTHER } \\
\cline { 2 - 7 } & No. & Rate & No. & Rate & No. & Rate \\
\hline \hline Motor Vehicle & 19,128 & 1.2 & 2,139 & 1.2 & 359 & 0.7 \\
\hline Homicide & 9,138 & 0.6 & 2,479 & 1.4 & 1,106 & 2.0 \\
\hline Machine & 11,028 & 0.7 & 1,044 & 0.6 & 174 & 0.3 \\
\hline Fall & 7,862 & 0.5 & 835 & 0.5 & 175 & 0.3 \\
\hline Electrocution & 5,696 & 0.4 & 444 & 0.3 & 51 & 0.1 \\
\hline Struck by Falling Object & 5,075 & 0.3 & 769 & 0.4 & 70 & 0.1 \\
\hline Air Transport & 3,140 & 0.2 & 57 & $<0.1$ & 51 & 0.1 \\
\hline Suicide & 2,855 & 0.2 & 179 & 0.1 & 103 & 0.2 \\
\hline Nature/Environment & 2,072 & 0.1 & 255 & 0.1 & 41 & 0.1 \\
\hline Explosion & 2,025 & 0.1 & 264 & 0.1 & 41 & 0.1 \\
\hline Flying Object/Caught In & 1,847 & 0.1 & 256 & 0.1 & 41 & 0.1 \\
\hline Water Transport & 1,355 & 0.1 & 197 & 0.1 & 236 & 0.4 \\
\hline Suffocation & 1,504 & 0.1 & 172 & 0.1 & 26 & $<0.1$ \\
\hline Fire & 1,308 & 0.1 & 226 & 0.1 & 30 & 0.1 \\
\hline Poisoning & 1,254 & 0.1 & 162 & 0.1 & 23 & $<0.1$ \\
\hline Drowning & 1,002 & 0.1 & 274 & 0.2 & 61 & 0.1 \\
\hline Rail Transport & 561 & $<0.1$ & 81 & $<0.1$ & 8 & $<0.1$ \\
\hline Other & 2,153 & 0.1 & 370 & 0.2 & 71 & 0.1 \\
\hline
\end{tabular}

"Numbers not reported for "unknown" or "not classified" categories. 
Table US-11. Number ${ }^{*+}$ of Traumatic Occupational Fatalities by Cause of Death and Age Group, US, 1980-1995.

\begin{tabular}{|l|c|c|c|c|c|c|c|c|}
\hline \multirow{2}{*}{ CAUSE OF DEATH } & \multicolumn{7}{|c|}{ AGE GROUP (IN YEARS) } \\
\cline { 2 - 9 } & $\mathbf{1 6 - 1 7}$ & $\mathbf{1 8 - 1 9}$ & $\mathbf{2 0 - 2 4}$ & $\mathbf{2 5 - 3 4}$ & $\mathbf{3 5 - 4 4}$ & $\mathbf{4 5 - 5 4}$ & $\mathbf{5 5 - 6 4}$ & $\mathbf{6 5 +}$ \\
\hline \hline Motor Vehicle & 223 & 567 & 2,235 & 5,708 & 4,757 & 3,961 & 2,950 & 1,298 \\
\hline Homicide & 113 & 312 & 1,314 & 3,379 & 3,031 & 2,207 & 1,572 & 908 \\
\hline Machine & 143 & 392 & 1,261 & 2,591 & 2,089 & 1,911 & 2,038 & 1,906 \\
\hline Fall & 53 & 187 & 810 & 2,072 & 1,776 & 1,678 & 1,619 & 867 \\
\hline Electrocution & 92 & 265 & 1,094 & 2,223 & 1,332 & 735 & 385 & 104 \\
\hline Struck by Falling Object & 34 & 157 & 596 & 1,473 & 1,355 & 1,161 & 827 & 380 \\
\hline Air Transport & 4 & 18 & 258 & 1,035 & 943 & 636 & 301 & 62 \\
\hline Suicide & 19 & 61 & 282 & 626 & 752 & 668 & 536 & 210 \\
\hline Nature/Environment & 30 & 66 & 231 & 538 & 523 & 374 & 360 & 265 \\
\hline Explosion & 15 & 59 & 249 & 698 & 612 & 391 & 251 & 68 \\
\hline Flying Object/Caught In & 20 & 63 & 283 & 565 & 459 & 382 & 295 & 105 \\
\hline Water Transport & 16 & 60 & 295 & 568 & 393 & 267 & 164 & 45 \\
\hline Suffocation & 30 & 76 & 220 & 502 & 363 & 255 & 188 & 77 \\
\hline Fire & 10 & 33 & 165 & 441 & 331 & 268 & 194 & 143 \\
\hline Poisoning & 23 & 56 & 198 & 467 & 350 & 198 & 110 & 53 \\
\hline Drowning & 33 & 60 & 235 & 380 & 264 & 169 & 151 & 65 \\
\hline Rail Transport & - & 10 & 29 & 145 & 174 & 163 & 129 & 10 \\
\hline Other & 26 & 52 & 201 & 531 & 548 & 466 & 478 & 316 \\
\hline
\end{tabular}

Numbers not reported for cells with less than 3 deaths.

†Numbers not reported for "unknown" or "not classified" categories. 
Table US-12. Average Annual Rate (per 100,000 workers) of Traumatic Occupational Fatalities by Cause of Death and Age Group, US, 1980-1995.

\begin{tabular}{|l|c|c|c|c|c|c|c|c|}
\hline \multirow{2}{*}{ CAUSE OF DEATH } & \multicolumn{7}{|c|}{ AGE GROUP (IN YEARS) } \\
\cline { 2 - 9 } & $\mathbf{1 6 - 1 7}$ & $\mathbf{1 8 - 1 9}$ & $\mathbf{2 0 - 2 4}$ & $\mathbf{2 5 - 3 4}$ & $\mathbf{3 5 - 4 4}$ & $\mathbf{4 5 - 5 4}$ & $\mathbf{5 5 - 6 4}$ & $\mathbf{6 5 +}$ \\
\hline \hline Motor Vehicle & 0.5 & 0.9 & 1.0 & 1.1 & 1.1 & 1.3 & 1.6 & 2.5 \\
\hline Homicide & 0.3 & 0.5 & 0.6 & 0.7 & 0.7 & 0.7 & 0.9 & 1.8 \\
\hline Machine & 0.4 & 0.6 & 0.6 & 0.5 & 0.5 & 0.6 & 1.1 & 3.7 \\
\hline Fall & 0.1 & 0.3 & 0.4 & 0.4 & 0.4 & 0.6 & 0.9 & 1.7 \\
\hline Electrocution & 0.2 & 0.4 & 0.5 & 0.4 & 0.3 & 0.2 & 0.2 & 0.2 \\
\hline Struck by Falling Object & 0.1 & 0.2 & 0.3 & 0.3 & 0.3 & 0.4 & 0.5 & 0.7 \\
\hline Air Transport & $<0.1$ & $<0.1$ & 0.1 & 0.2 & 0.2 & 0.2 & 0.2 & 0.1 \\
\hline Suicide & $<0.1$ & 0.1 & 0.1 & 0.1 & 0.2 & 0.2 & 0.3 & 0.4 \\
\hline Nature/Environment & 0.1 & 0.1 & 0.1 & 0.1 & 0.1 & 0.1 & 0.2 & 0.5 \\
\hline Explosion & $<0.1$ & 0.1 & 0.1 & 0.1 & 0.1 & 0.1 & 0.1 & 0.1 \\
\hline Flying Object/Caught In & $<0.1$ & 0.1 & 0.1 & 0.1 & 0.1 & 0.1 & 0.2 & 0.2 \\
\hline Water Transport & $<0.1$ & 0.1 & 0.1 & 0.1 & 0.1 & 0.1 & 0.1 & 0.1 \\
\hline Suffocation & 0.1 & 0.1 & 0.1 & 0.1 & 0.1 & 0.1 & 0.1 & 0.2 \\
\hline Fire & $<0.1$ & 0.1 & 0.1 & 0.1 & 0.1 & 0.1 & 0.1 & 0.3 \\
\hline Poisoning & 0.1 & 0.1 & 0.1 & 0.1 & 0.1 & 0.1 & 0.1 & 0.1 \\
\hline Drowning & 0.1 & 0.1 & 0.1 & 0.1 & 0.1 & 0.1 & 0.1 & 0.1 \\
\hline Rail Transport & - & $<0.1$ & $<0.1$ & $<0.1$ & $<0.1$ & 0.1 & 0.1 & $<0.1$ \\
\hline Other & 0.1 & 0.1 & 0.1 & 0.1 & 0.1 & 0.2 & 0.3 & 0.6 \\
\hline
\end{tabular}

'Rates not calculated for categories with less than 3 deaths or less than 20,000 employed.

Table US-13. Number and Average Annual Rate* (per 100,000 workers) of Traumatic Occupational Fatalities by Industry Division, US, 1980-1995.

\begin{tabular}{|l|c|c|}
\hline INDUSTRY DIVISION & $\begin{array}{c}\text { NUMBER OF } \\
\text { DEATHS }\end{array}$ & $\begin{array}{c}\text { RATE PER } \\
\mathbf{1 0 0 , 0 0 0}\end{array}$ \\
\hline \hline Construction & 17,140 & 15.3 \\
\hline Trans/Comm/PU & 15,604 & 12.6 \\
\hline Manufacturing & 14,034 & 4.2 \\
\hline Ag/For/Fish & 10,737 & 19.6 \\
\hline Services & 10,056 & 1.7 \\
\hline Retail Trade & 8,631 & 2.9 \\
\hline Public Admin & 4,343 & 5.1 \\
\hline Mining & 3,995 & 30.4 \\
\hline Wholesale Trade & 2,741 & 3.8 \\
\hline Finance/lnsur/RE & 1,271 & 1.1 \\
\hline Not Classified & 4,786 & - \\
\hline
\end{tabular}

- Rates not calculated for "unknown" or "not classified" categories. 
Table US-14. Number ${ }^{*}$ and Rate (per 100,000 workers) of Traumatic Occupational Fatalities by Industry Division and Year, US, 1980-1995.

\begin{tabular}{|c|c|c|c|c|c|c|c|c|c|c|c|c|c|c|c|c|c|}
\hline \multirow{2}{*}{\multicolumn{2}{|c|}{ INDUSTRY DIVISION }} & \multicolumn{16}{|c|}{ YEAR OF DEATH } \\
\hline & & 1980 & 1981 & 1982 & 1983 & 1984 & 1985 & 1986 & 1987 & 1988 & 1989 & 1990 & 1991 & 1992 & 1993 & 1994 & 1995 \\
\hline \multirow{2}{*}{ Ag/For/Fish } & No. & 821 & 794 & 744 & 658 & 717 & 752 & 653 & 702 & 645 & 683 & 603 & 615 & 598 & 608 & 587 & 557 \\
\hline & Rate & 23.7 & 23.0 & 20.8 & 18.6 & 20.7 & 22.5 & 19.5 & 20.6 & 19.4 & 20.2 & 18.0 & 18.1 & 17.7 & 18.7 & 16.4 & 15.5 \\
\hline \multirow{2}{*}{ Mining } & No. & 414 & 505 & 368 & 289 & 357 & 277 & 218 & 174 & 162 & 193 & 219 & 175 & 147 & 170 & 168 & 159 \\
\hline & Rate & 44.0 & 46.8 & 35.8 & 31.4 & 37.3 & 29.5 & 24.8 & 21.3 & 21.5 & 26.8 & 30.0 & 23.9 & 22.1 & 25.4 & 25.1 & 25.4 \\
\hline \multirow{2}{*}{ Construction } & No. & 1,271 & 1,230 & 1,087 & 1,035 & 1,113 & 1,190 & 1,102 & 1,197 & 1,098 & 1,104 & 1,077 & 893 & 890 & 885 & 967 & 1,001 \\
\hline & Rate & 21.0 & 20.8 & 18.9 & 16.8 & 16.7 & 17.0 & 15.1 & 16.1 & 14.4 & 14.4 & 14.0 & 12.6 & 12.7 & 12.3 & 12.9 & 13.1 \\
\hline \multirow{2}{*}{ Manufacturing } & No. & 1,135 & 1,089 & 952 & 884 & 967 & 926 & 893 & 898 & 885 & 866 & 838 & 793 & 736 & 713 & 727 & 732 \\
\hline & Rate & 5.3 & 5.1 & 4.7 & 4.4 & 4.6 & 4.4 & 4.3 & 4.3 & 4.2 & 4.0 & 4.0 & 3.9 & 3.7 & 3.6 & 3.6 & 3.6 \\
\hline \multirow{2}{*}{ Trans/Comm/PU } & No. & 1,223 & 1,139 & 1,078 & 961 & 1,041 & 1,101 & 938 & 918 & 970 & 987 & 847 & 853 & 828 & 927 & 897 & 896 \\
\hline & Rate & 19.1 & 17.5 & 16.5 & 13.8 & 14.1 & 14.6 & 12.3 & 11.6 & 12.0 & 12.2 & 10.4 & 10.4 & 10.0 & 10.9 & 10.3 & 10.3 \\
\hline \multirow{2}{*}{ Wholesale Trade } & No. & 195 & 193 & 165 & 170 & 176 & 182 & 167 & 159 & 172 & 152 & 167 & 169 & 153 & 169 & 177 & 175 \\
\hline & Rate & 5.1 & 4.9 & 4.0 & 3.9 & 4.2 & 4.2 & 3.8 & 3.5 & 3.8 & 3.3 & 3.6 & 3.6 & 3.2 & 3.7 & 3.8 & 3.5 \\
\hline \multirow{2}{*}{ Retail Trade } & No. & 625 & 618 & 567 & 485 & 460 & 506 & 439 & 489 & 497 & 474 & 544 & 581 & 574 & 634 & 631 & 507 \\
\hline & Rate & 3.9 & 3.8 & 3.4 & 2.9 & 2.6 & 2.8 & 2.4 & 2.6 & 2.6 & 2.4 & 2.8 & 3.0 & 2.9 & 3.1 & 3.0 & 2.4 \\
\hline \multirow{2}{*}{ Finance/Insur/RE } & No. & 75 & 91 & 71 & 72 & 84 & 63 & 76 & 84 & 73 & 77 & 75 & 89 & 76 & 85 & 88 & 92 \\
\hline & Rate & 1.3 & 1.5 & 1.1 & 1.1 & 1.2 & 0.9 & 1.0 & 1.1 & 0.9 & 1.0 & 0.9 & 1.1 & 1.0 & 1.1 & 1.1 & 1.2 \\
\hline \multirow{2}{*}{ Services } & No. & 714 & 642 & 649 & 597 & 590 & 621 & 563 & 595 & 635 & 625 & 606 & 656 & 596 & 642 & 678 & 647 \\
\hline & Rate & 2.6 & 2.2 & 2.2 & 1.9 & 1.8 & 1.9 & 1.6 & 1.7 & 1.7 & 1.6 & 1.6 & 1.7 & 1.5 & 1.5 & 1.6 & 1.5 \\
\hline \multirow{2}{*}{ Public Admin } & No. & 323 & 312 & 284 & 290 & 262 & 249 & 270 & 283 & 295 & 254 & 213 & 183 & 246 & 261 & 273 & 345 \\
\hline & Rate & 6.2 & 6.0 & 5.4 & 6.2 & 5.5 & 5.0 & 5.3 & 5.4 & 5.4 & 4.6 & 3.8 & 3.2 & 4.4 & 4.5 & 4.7 & 5.8 \\
\hline
\end{tabular}

"Numbers not reported for "unknown" or "not classified" categories. 
Table US-15. Number ${ }^{*}$ of Traumatic Occupational Fatalities by Cause of Death and Industry Division, US, 1980-1995.

\begin{tabular}{|c|c|c|c|c|c|c|c|c|c|c|}
\hline \multirow[b]{2}{*}{ CAUSE OF DEATH } & \multicolumn{10}{|c|}{ INDUSTRY DIVISION } \\
\hline & $\begin{array}{c}\text { AG/FORI } \\
\text { FSH }\end{array}$ & MINING & $\begin{array}{c}\text { CONSTRUC- } \\
\text { TION }\end{array}$ & $\begin{array}{l}\text { MANUFAC- } \\
\text { TURING }\end{array}$ & $\begin{array}{l}\text { TRANS/ } \\
\text { COMM } / \\
\text { PU }\end{array}$ & $\begin{array}{c}\text { WHOLESALE } \\
\text { TRADE }\end{array}$ & $\begin{array}{l}\text { RETAIL } \\
\text { TRADE }\end{array}$ & $\begin{array}{l}\text { FINANCE } \\
\text { INSUR/RE }\end{array}$ & SERVICES & $\begin{array}{l}\text { PUBLIC } \\
\text { ADMIN }\end{array}$ \\
\hline Motor Vehicle & 1,767 & 664 & 2,846 & 2,100 & 7,268 & 1,061 & 1,302 & 277 & 2,009 & 1,350 \\
\hline Homicide & 281 & 36 & 493 & 887 & 1,258 & 232 & 4,917 & 429 & 2,329 & 1,193 \\
\hline Machine & 3,625 & 952 & 2,272 & 2,616 & 747 & 327 & 319 & 65 & 641 & 194 \\
\hline Fall & 573 & 227 & 4,456 & 1,115 & 583 & 178 & 311 & 108 & 913 & 198 \\
\hline Electrocution & 655 & 276 & 2,293 & 813 & 1,018 & 126 & 142 & 32 & 481 & 111 \\
\hline Struck by Falling Object & 597 & 539 & 1,261 & 2,043 & 449 & 140 & 147 & 13 & 474 & 95 \\
\hline Air Transport & 287 & 81 & 116 & 312 & 1,327 & 68 & 90 & 76 & 451 & 321 \\
\hline Suicide & 241 & 24 & 263 & 391 & 251 & 119 & 526 & 133 & 815 & 186 \\
\hline Nature/Environment & 584 & 173 & 434 & 461 & 217 & 47 & 74 & 13 & 207 & 55 \\
\hline Explosion & 87 & 312 & 354 & 719 & 209 & 103 & 118 & 11 & 274 & 45 \\
\hline Flying Object/Caught In & 176 & 173 & 428 & 654 & 286 & 70 & 71 & 14 & 151 & 34 \\
\hline Water Transport & 728 & 63 & 115 & 107 & 557 & 14 & 35 & - & 83 & 37 \\
\hline Suffocation & 220 & 102 & 672 & 214 & 96 & 84 & 53 & 7 & 122 & 37 \\
\hline Fire & 125 & 93 & 220 & 446 & 104 & 45 & 104 & 12 & 197 & 150 \\
\hline Poisoning & 135 & 101 & 209 & 306 & 160 & 31 & 86 & 13 & 269 & 36 \\
\hline Drowning & 325 & 76 & 212 & 115 & 203 & 16 & 27 & 17 & 201 & 61 \\
\hline Rail Transport & 12 & 15 & 24 & 64 & 490 & 13 & 8 & - & 21 & 7 \\
\hline Other & 262 & 67 & 408 & 596 & 285 & 55 & 227 & 34 & 331 & 186 \\
\hline
\end{tabular}

Numbers not reported for cells with less than 3 deaths.

'Numbers not reported for "unknown" or "not classified" categories. 
Table US-16. Average Annual Rate* (per 100,000 workers) of Traumatic Occupational Fatalities by Cause of Death and Industry Division, US, 1980-1995.

\begin{tabular}{|c|c|c|c|c|c|c|c|c|c|c|}
\hline \multirow[b]{2}{*}{ CAUSE OF DEATH } & \multicolumn{10}{|c|}{ INDUSTRY DIVISION } \\
\hline & $\begin{array}{c}\text { AG/FORI } \\
\text { FISH }\end{array}$ & MINING & $\begin{array}{c}\text { CONSTRUC- } \\
\text { TION }\end{array}$ & $\begin{array}{c}\text { MANUFAC- } \\
\text { TURING }\end{array}$ & $\begin{array}{c}\text { TRANS/ } \\
\text { COMM / } \\
\text { PU }\end{array}$ & $\begin{array}{c}\text { WHOLESALE } \\
\text { TRADE }\end{array}$ & $\begin{array}{l}\text { RETAIL } \\
\text { TRADE }\end{array}$ & $\begin{array}{l}\text { FINANCEI } \\
\text { INSUR/RE }\end{array}$ & SERVICES & $\begin{array}{l}\text { PUBLIC } \\
\text { ADMIN }\end{array}$ \\
\hline Motor Vehicle & 3.2 & 5.1 & 2.5 & 0.6 & 5.9 & 1.5 & 0.4 & 0.2 & 0.3 & 1.6 \\
\hline Homicide & 0.5 & 0.3 & 0.4 & 0.3 & 1.0 & 0.3 & 1.7 & 0.4 & 0.4 & 1.4 \\
\hline Machine & 6.6 & 7.3 & 2.0 & 0.8 & 0.6 & 0.5 & 0.1 & 0.1 & 0.1 & 0.2 \\
\hline Fall & 1.0 & 1.7 & 4.0 & 0.3 & 0.5 & 0.2 & 0.1 & 0.1 & 0.2 & 0.2 \\
\hline Electrocution & 1.2 & 2.1 & 2.1 & 0.2 & 0.8 & 0.2 & $<0.1$ & $<0.1$ & 0.1 & 0.1 \\
\hline Struck by Falling Object & 1.1 & 4.1 & 1.1 & 0.6 & 0.4 & 0.2 & $<0.1$ & $<0.1$ & 0.1 & 0.1 \\
\hline Air Transport & 0.5 & 0.6 & 0.1 & 0.1 & 1.1 & 0.1 & $<0.1$ & 0.1 & 0.1 & 0.4 \\
\hline Suicide & 0.4 & 0.2 & 0.2 & 0.1 & 0.2 & 0.2 & 0.2 & 0.1 & 0.1 & 0.2 \\
\hline Nature/Environment & 1.1 & 1.3 & 0.4 & 0.1 & 0.2 & 0.1 & $<0.1$ & $<0.1$ & $<0.1$ & 0.1 \\
\hline Explosion & 0.2 & 2.4 & 0.3 & 0.2 & 0.2 & 0.1 & $<0.1$ & $<0.1$ & $<0.1$ & 0.1 \\
\hline Flying Object/Caught In & 0.3 & 1.3 & 0.4 & 0.2 & 0.2 & 0.1 & $<0.1$ & $<0.1$ & $<0.1$ & $<0.1$ \\
\hline Water Transport & 1.3 & 0.5 & 0.1 & $<0.1$ & 0.5 & $<0.1$ & $<0.1$ & - & $<0.1$ & $<0.1$ \\
\hline Suffocation & 0.4 & 0.8 & 0.6 & 0.1 & 0.1 & 0.1 & $<0.1$ & $<0.1$ & $<0.1$ & $<0.1$ \\
\hline Fire & 0.2 & 0.7 & 0.2 & 0.1 & 0.1 & 0.1 & $<0.1$ & $<0.1$ & $<0.1$ & 0.2 \\
\hline Poisoning & 0.2 & 0.8 & 0.2 & 0.1 & 0.1 & $<0.1$ & $<0.1$ & $<0.1$ & $<0.1$ & $<0.1$ \\
\hline Drowning & 0.6 & 0.6 & 0.2 & $<0.1$ & 0.2 & $<0.1$ & $<0.1$ & $<0.1$ & $<0.1$ & 0.1 \\
\hline Rail Transport & $<0.1$ & 0.1 & $<0.1$ & $<0.1$ & 0.4 & $<0.1$ & $<0.1$ & - & $<0.1$ & $<0.1$ \\
\hline Other & 0.5 & 0.5 & 0.4 & 0.2 & 0.2 & 0.1 & 0.1 & $<0.1$ & 0.1 & 0.2 \\
\hline
\end{tabular}

'Rates not calculated for categories with less than 3 deaths or less than 20,000 employed. 


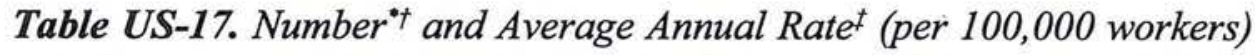
of Traumatic Occupational Fatalities by Industry Division and Age Group, US, 1983-1995.

\begin{tabular}{|c|c|c|c|c|c|c|c|c|c|}
\hline \multirow{2}{*}{\multicolumn{2}{|c|}{ INDUSTRY DIVISION }} & \multicolumn{8}{|c|}{ AGE GROUP (IN YEARS) } \\
\hline & & \multirow{2}{*}{$\begin{array}{c}16-17 \\
48 \\
\end{array}$} & \multirow{2}{*}{\begin{tabular}{|c|}
$18-19$ \\
196
\end{tabular}} & \multirow{2}{*}{$\begin{array}{c}20-24 \\
734\end{array}$} & \multirow{2}{*}{$\begin{array}{l}25-34 \\
1,609\end{array}$} & \multirow{2}{*}{$\begin{array}{l}35-44 \\
1,362\end{array}$} & \multirow{2}{*}{\begin{tabular}{|l|}
$45-54$ \\
1,201
\end{tabular}} & \multirow{2}{*}{$\frac{55-64}{1,329}$} & \multirow{2}{*}{$\begin{array}{c}65+ \\
1,884 \\
\end{array}$} \\
\hline & No. & & & & & & & & \\
\hline & Rate & 2.8 & 10.5 & 14.7 & 15.1 & 15.2 & 18.1 & 22.8 & 48.0 \\
\hline \multirow{2}{*}{ Mining } & No. & 6 & 39 & 321 & 939 & 651 & 428 & 230 & 91 \\
\hline & Rate & 28.0 & 35.5 & 42.5 & 29.0 & 21.1 & 23.9 & 24.8 & 59.5 \\
\hline \multirow{2}{*}{ Construction } & No. & 51 & 349 & 1,559 & 3,895 & 3,113 & 2,275 & 1,694 & 608 \\
\hline & Rate & 6.2 & 12.9 & 13.3 & 12.7 & 13.0 & 15.5 & 19.9 & 36.4 \\
\hline \multirow{2}{*}{ Manufacturing } & No. & 17 & 202 & 1,011 & 2,750 & 2,548 & 2,006 & 1,671 & 651 \\
\hline & Rate & 1.2 & 4.0 & 3.7 & 3.4 & 3.5 & 4.0 & 5.8 & 16.0 \\
\hline \multirow{2}{*}{ Trans/Comm/PU } & No. & 8 & 125 & 872 & 3,327 & 3,295 & 2,451 & 1,618 & 460 \\
\hline & Rate & 2.4 & 10.0 & 10.4 & 10.9 & 10.4 & 12.0 & 16.0 & 30.9 \\
\hline \multirow{2}{*}{ Wholesale Trade } & No. & 5 & 56 & 193 & 593 & 512 & 395 & 287 & 144 \\
\hline & Rate & 1.2 & 4.7 & 3.1 & 3.2 & 3.3 & 4.0 & 4.7 & 8.2 \\
\hline \multirow{2}{*}{ Retail Trade } & No. & 35 & 215 & 762 & 1,624 & 1,500 & 1,171 & 931 & 574 \\
\hline & Rate & 0.2 & 0.9 & 1.7 & 2.6 & 3.4 & 4.0 & 4.8 & 8.0 \\
\hline \multirow{2}{*}{ Finance/Insur/RE } & No. & - & 9 & 59 & 231 & 220 & 223 & 185 & 107 \\
\hline & Rate & - & 0.5 & 0.5 & 0.8 & 0.9 & 1.3 & 1.9 & 3.2 \\
\hline \multirow{2}{*}{ Services } & No. & 21 & 152 & 778 & 2,075 & 1,838 & 1,434 & 1,121 & 632 \\
\hline & Rate & 0.3 & 1.1 & 1.5 & 1.6 & 1.4 & 1.7 & 2.2 & 3.8 \\
\hline \multirow{2}{*}{ Public Admin } & No. & - & 33 & 238 & 1,021 & 929 & 625 & 421 & 157 \\
\hline & Rate & - & 5.6 & 5.4 & 5.3 & 4.3 & 4.2 & 5.6 & 9.4 \\
\hline
\end{tabular}

Numbers not reported for cells with less than 3 deaths.

†Numbers not reported for "unknown" or "not classified" categories.

${ }^{\ddagger}$ Rates not calculated for categories with less than 3 deaths or less than 20,000 employed. 
Table US-18. Number and Average Annual Rate* (per 100,000 workers) of Traumatic Occupational Fatalities by Detailed Industry Groupings, US, 1983-1995.

\begin{tabular}{|l|c|c|}
\hline \multicolumn{1}{|c|}{ DETAlLED INDUSTRY } & $\begin{array}{c}\text { NO. OF } \\
\text { DEATHS }\end{array}$ & RATE \\
\hline \hline Ag/For/Fish & & \\
\hline Ag Production & 6,139 & 20.0 \\
\hline Ag Services & 1,183 & 10.1 \\
\hline Forestry \& Fisheries & 1,056 & 47.7 \\
\hline Mining & & \\
\hline Metal/Coal/Nonmetal Mining & 1,262 & 30.0 \\
\hline Oil and Gas Extraction & 1,446 & 24.6 \\
\hline Construction & 13,552 & 14.3 \\
\hline Manufacturing & & \\
\hline Food \& Kindred Prod & 1,015 & 4.5 \\
\hline Textile Mill Prod & 227 & 2.5 \\
\hline Apparel \& Other Textile Pr & 84 & 0.6 \\
\hline Paper \& Allied Products & 319 & 3.5 \\
\hline Printing/Publishing/Allied & 347 & 1.5 \\
\hline Chemical/Petroleum/Rubber & 1,099 & 3.9 \\
\hline Lumber \& Wood & 2,843 & 29.8 \\
\hline Furniture & 141 & 1.7 \\
\hline Stone/Clay/Concrete & 459 & 6.0 \\
\hline Primary Metals & 1,006 & 9.7 \\
\hline Fabricated Metals & 453 & 2.7 \\
\hline Mach, Ex Elect & 640 & 2.0 \\
\hline Elect Mach, Equip Supplies & 346 & 1.3 \\
\hline Motor Vehicles Equip & 332 & 2.2 \\
\hline Aircraft \& Parts & 153 & 2.0 \\
\hline Other Transport Equip & 337 & 3.6 \\
\hline Prof \& Photo Equip/Watches & 50 & 0.5 \\
\hline Toys/Amusement/Sporting Goods & 15 & 0.8 \\
\hline Misc \& NEC Industries & 992 & 12.1 \\
\hline Trans/Comm/PU & & \\
\hline Trucking/Warehousing/Storage & 5,966 & 23.3 \\
\hline Other Transportation & 3,936 & 10.2 \\
\hline Telephone Communications & 1.5 \\
\hline Other Communications & 3.5 \\
\hline Electric Light and Power & 9.4 \\
\hline Other Utility/Sanitary Service & 9.0 \\
\hline Wholesale Trade & 222 \\
\hline
\end{tabular}

\begin{tabular}{|c|c|c|}
\hline DETAILED INDUSTRY & $\begin{array}{l}\text { NO. OF } \\
\text { DEATHS }\end{array}$ & RATE \\
\hline \multicolumn{3}{|l|}{ Retail Trade } \\
\hline Food Stores & 1,771 & 4.3 \\
\hline Motor Veh/Auto Supply Dealer & 1,138 & 4.2 \\
\hline Apparel \& Accessory Stores & 126 & 1.0 \\
\hline Eating \& Drinking Places & 1,482 & 2.0 \\
\hline Other Retail Trade & 2,304 & 2.4 \\
\hline \multicolumn{3}{|l|}{ Finance/Insur/RE } \\
\hline Banking and Other Finance & 288 & 0.7 \\
\hline Insurance and Real Estate & 746 & 1.3 \\
\hline \multicolumn{3}{|l|}{ Services } \\
\hline Business Services & 1,583 & 2.6 \\
\hline Automobile and Repair Services & 2,086 & 7.9 \\
\hline Private Household Services & 162 & 1.1 \\
\hline Pers Serv Exc Priv Household & 912 & 2.1 \\
\hline Entertainment \& Rec Services & 684 & 3.3 \\
\hline Hospitals & 390 & 0.6 \\
\hline Health Services, Exc Hosp & 405 & 0.7 \\
\hline Educational Services & 823 & 0.7 \\
\hline Other Professional Services. & 1,006 & 1.1 \\
\hline \multicolumn{3}{|l|}{ Public Admin } \\
\hline Justice, Pub Order, \& Safety & 1,990 & 7.9 \\
\hline Admin of Hum Res Programs & 47 & 0.5 \\
\hline National Sec/Internal Affairs & 311 & 2.9 \\
\hline Other Pub Admin & 1,035 & 4.1 \\
\hline Not Classified & 3,419 & - \\
\hline
\end{tabular}

- Rates not calculated for "unknown" or "not classified" categories. 
Table US-19. Number of Traumatic Occupational Fatalities

by Selected Detailed Industry Groupings" and Year, US, 1983-1995.

\begin{tabular}{|c|c|c|c|c|c|c|c|c|c|c|c|c|c|}
\hline \multirow{2}{*}{ DETAILED INDUSTRY } & \multicolumn{13}{|c|}{ YEAR OF DEATH } \\
\hline & 1983 & 1984 & 1985 & 1986 & 1987 & 1988 & 1989 & 1990 & 1991 & 1992 & 1993 & 1994 & 1995 \\
\hline Forestry \& Fisheries & 67 & 75 & 93 & 66 & 73 & 77 & 125 & 85 & 87 & 92 & 81 & 77 & 58 \\
\hline Metal/Coal/Nonmetal Mining & 113 & 158 & 92 & 113 & 91 & 69 & 88 & 100 & 99 & 89 & 93 & 70 & 87 \\
\hline Lumber \& Wood MFG & 238 & 237 & 246 & 251 & 259 & 245 & 250 & 224 & 211 & 204 & 163 & 158 & 157 \\
\hline Oil and Gas Extraction & 176 & 199 & 185 & 105 & 83 & 93 & 105 & 119 & 76 & 58 & 77 & 98 & 72 \\
\hline Trucking/Warehousing/S & 476 & 545 & 551 & 480 & 460 & 533 & 493 & 406 & 376 & 371 & 405 & 428 & 442 \\
\hline Ag Production & 523 & 549 & 586 & 502 & 541 & 494 & 449 & 420 & 430 & 429 & 426 & 401 & 389 \\
\hline Construction & 1,035 & 1,113 & 1,190 & 1,102 & 1,197 & 1,098 & 1,104 & 1,077 & 893 & 890 & 885 & 967 & 1,001 \\
\hline Other Transportation & 295 & 301 & 326 & 287 & 291 & 270 & 297 & 284 & 330 & 309 & 354 & 306 & 286 \\
\hline Ag Services & 68 & 93 & 73 & 85 & 88 & 74 & 109 & 98 & 98 & 77 & 101 & 109 & 110 \\
\hline Primary Metals MFG & 93 & 95 & 88 & 92 & 90 & 89 & 75 & 73 & 62 & 62 & 68 & 55 & 64 \\
\hline Electric Light and Power & 74 & 79 & 87 & 78 & 64 & 74 & 78 & 62 & 39 & 50 & 42 & 37 & 50 \\
\hline Other Utility/Sanitary Service & 80 & 91 & 103 & 66 & 72 & 61 & 89 & 66 & 75 & 70 & 87 & 87 & 75 \\
\hline Automobile and Repair Services & 171 & 143 & 171 & 150 & 159 & 181 & 166 & 165 & 157 & 129 & 178 & 130 & 186 \\
\hline Justice, Pub Order, \& Safety & 150 & 138 & 153 & 153 & 159 & 183 & 168 & 120 & 123 & 147 & 167 & 152 & 177 \\
\hline Stone/Clay/Concrete MFG & 48 & 54 & 59 & 41 & 42 & 29 & 26 & 25 & 30 & 30 & 30 & 21 & 24 \\
\hline
\end{tabular}

- The selected groupings had the highest rates per 100,000 workers. 
Table US-20. Rate (per 100,000 workers) of Traumatic Occupational Fatalities by Selected Detailed Industry Groupings" and Year, US, 1983-1995.

\begin{tabular}{|c|c|c|c|c|c|c|c|c|c|c|c|c|c|}
\hline \multirow{2}{*}{ DETAILED INDUSTRY } & \multicolumn{13}{|c|}{ YEAR OF DEATH } \\
\hline & 1983 & 1984 & 1985 & 1986 & 1987 & 1988 & 1989 & 1990 & 1991 & 1992 & 1993 & 1994 & 1995 \\
\hline Forestry \& Fisheries & 41.3 & 49.5 & 58.6 & 35.2 & 38.2 & 49.8 & 688.3 & 48.3 & 54.1 & 52.1 & 43.9 & 444.2 & 37.8 \\
\hline Metal/Coal/Nonmetal Mining & 33.0 & 46.7 & 26.4 & 32.8 & 26.6 & 21.3 & 26.2 & 29.1 & 31.7 & 29.8 & 30.8 & 24.9 & 30.2 \\
\hline Lumber \& Wood MFG & 35.9 & 33.5 & 35.6 & 36.2 & 34.7 & 32.0 & 31.6 & 28.5 & 29.4 & 29.4 & 22.8 & 21.4 & 19.2 \\
\hline Oil and Gas Extraction & 30.1 & 32.5 & 31.2 & 19.4 & 17.4 & 21.7 & 27.4 & 30.8 & 17.9 & 15.9 & 20.6 & 25.5 & 21.7 \\
\hline Trucking/Warehousing/Storage & 31.1 & 32.2 & 31.1 & 26.9 & 24.4 & 27.2 & 25.0 & 20.2 & 18.3 & 17.9 & 18.6 & 18.3 & 19.0 \\
\hline Ag Production & 19.0 & 20.5 & 23.7 & 20.9 & 22.8 & 21.5 & 19.8 & 19.0 & 18.9 & 19.1 & 20.5 & 17.2 & 16.5 \\
\hline Construction & 16.7 & 16.6 & 17.0 & 15.1 & 16.0 & 14.4 & 14.3 & 13.8 & 12.5 & 12.5 & 12.1 & 12.9 & 13.0 \\
\hline Other Transportation & 11.6 & 11.5 & 12.1 & 10.1 & 9.9 & 9.0 & 9.7 & 9.3 & 11.0 & 10.3 & 11.2 & 9.4 & 8.8 \\
\hline Ag Services & 10.4 & 14.3 & 10.4 & 11.1 & 10.4 & 8.5 & 11.7 & 9.6 & 9.7 & 7.5 & 9.7 & 10.1 & 10.0 \\
\hline Primary Metals MFG & 11.6 & 11.1 & 10.8 & 11.9 & 11.2 & 11.2 & 9.0 & 8.6 & 7.9 & 8.0 & 9.3 & 7.3 & 8.2 \\
\hline Electric Light and Power & 11.6 & 12.0 & 13.3 & 12.1 & 9.4 & 11.0 & 11.8 & 8.8 & 5.5 & 7.4 & 6.5 & 5.8 & 7.9 \\
\hline Other Utility/Sanitary Service & 9.7 & 10.8 & 12.4 & 8.1 & 8.4 & 7.0 & 10.6 & 7.5 & 8.6 & 7.4 & 9.2 & 9.5 & 8.5 \\
\hline Automobile and Repair Services & 10.1 & 7.9 & 8.7 & 7.9 & 8.2 & 9.2 & 8.1 & 7.8 & 7.5 & 6.0 & 8.2 & 5.8 & 8.5 \\
\hline Justice, Pub Order, \& Safety & 9.5 & 8.5 & 9.2 & 8.9 & 8.6 & 9.5 & 8.7 & 6.0 & 5.9 & 7.0 & 7.7 & 6.7 & 7.7 \\
\hline Stone/Clay/Concrete MFG & 8.7 & 9.2 & 10.2 & 6.6 & 7.0 & 4.7 & 4.1 & 4.0 & 5.2 & 5.5 & 5.6 & 3.8 & 4.1 \\
\hline
\end{tabular}

- The selected groupings had the highest rates per 100,000 workers. 
Table US-21. Number of Traumatic Occupational Fatalities by Selected Detailed Industry Groupings" and Cause of Death, US, 1983-1995.

\begin{tabular}{|c|c|c|c|c|c|c|c|c|c|c|}
\hline \multirow[b]{2}{*}{ DETAILED INDUSTRY } & \multicolumn{10}{|c|}{ CAUSE OF DEATH } \\
\hline & $\begin{array}{l}\text { MOTOR } \\
\text { VEHICLE }\end{array}$ & HOMICIDE & MACHINE & FALL & $\begin{array}{l}\text { ELECTRO- } \\
\text { CUTION }\end{array}$ & \begin{tabular}{|c|} 
STRUCK \\
BY \\
FALLING
\end{tabular} & $\begin{array}{c}\text { AIR } \\
\text { TRANSPORT }\end{array}$ & SUICIDE & EXPLOSION & $\begin{array}{l}\text { NATURE/ } \\
\text { ENVIRON }\end{array}$ \\
\hline Forestry \& Fisheries & $\overline{51}$ & 22 & 36 & 20 & 20 & 33 & 28 & 16 & 3 & 30 \\
\hline Metal/Coal/Nonmetal Mining & 191 & 10 & 271 & 57 & 85 & 279 & 9 & 9 & 77 & 61 \\
\hline Lumber \& Wood MFG & 355 & 38 & 535 & 87 & 65 & 1,236 & 25 & 20 & 18 & 118 \\
\hline Oil and Gas Extraction & 280 & 17 & 388 & 85 & 104 & 70 & 32 & 13 & 125 & 56 \\
\hline Trucking/Warehousing/Storage & 4,532 & 204 & 224 & 114 & 98 & 213 & 19 & 69 & 65 & 67 \\
\hline Ag Production & 1,164 & 141 & 2,568 & 259 & 305 & 340 & 52 & 150 & 58 & 381 \\
\hline Construction & 2,352 & 374 & 1,784 & 3,543 & 1,754 & 970 & 85 & 226 & 272 & 354 \\
\hline Other Transportation & 539 & 734 & 186 & 145 & 51 & 73 & 962 & 80 & 31 & 59 \\
\hline Ag Services & 213 & 47 & 133 & 176 & 153 & 103 & 131 & 34 & 6 & 50 \\
\hline Primary Metals MFG & 95 & 41 & 233 & 112 & 56 & 88 & 5 & 16 & 60 & 35 \\
\hline Electric Light and Power & 80 & 15 & 40 & 74 & 445 & 20 & 12 & 9 & 24 & 13 \\
\hline Other Utility/Sanitary Service & 390 & 45 & 96 & 48 & 90 & 47 & 10 & 32 & 42 & 27 \\
\hline Automobile and Repair Services & 447 & 282 & 174 & 105 & 126 & 232 & 13 & 187 & 133 & 45 \\
\hline Justice, Pub Order, \& Safety & 665 & 746 & 21 & 56 & 22 & 18 & 97 & 93 & 16 & 13 \\
\hline Stone/Clay/Concrete MFG & 94 & 20 & 93 & 45 & 46 & 38 & 3 & 18 & 12 & 13 \\
\hline
\end{tabular}

- The selected groupings had the highest rates per 100,000 workers. 
Table US-22. Average Annual Rate (per 100,000 workers) of Traumatic Occupational Fatalities by Selected Detailed Industry Groupings" and Cause of Death, US, 1983-1995.

\begin{tabular}{|c|c|c|c|c|c|c|c|c|c|c|}
\hline \multirow[b]{2}{*}{ DETAILED INDUSTRY } & \multicolumn{10}{|c|}{ CAUSE OF DEATH } \\
\hline & $\begin{array}{l}\text { MOTOR } \\
\text { VEHICLE }\end{array}$ & HOMICIDE & MACHINE & FALL & $\begin{array}{l}\text { ELECTRO- } \\
\text { CUTION }\end{array}$ & $\begin{array}{c}\text { STRUCK } \\
\text { BY } \\
\text { FALLING }\end{array}$ & $\begin{array}{c}\text { AIR } \\
\text { TRANSPORT }\end{array}$ & SUICIDE & EXPLOSION & $\begin{array}{l}\text { NATUREI } \\
\text { ENVIRON }\end{array}$ \\
\hline Forestry \& Fisheries & 2.3 & 1.0 & 1.6 & 0.9 & 0.9 & 1.5 & 1.3 & 0.7 & 0.1 & 1.4 \\
\hline Metal/Coal/Nonmetal Mining & 4.5 & 0.2 & 6.5 & 1.4 & 2.0 & 6.6 & 0.2 & 0.2 & 1.8 & 1.5 \\
\hline Lumber \& Wood MFG & 3.7 & 0.4 & 5.6 & 0.9 & 0.7 & 13.0 & 0.3 & 0.2 & 0.2 & 1.2 \\
\hline Oil and Gas Extraction & 4.8 & 0.3 & 6.6 & 1.4 & 1.8 & 1.2 & 0.5 & 0.2 & 2.1 & 1.0 \\
\hline Trucking/Warehousing/Storage & 17.7 & 0.8 & 0.9 & 0.4 & 0.4 & 0.8 & 0.1 & 0.3 & 0.3 & 0.3 \\
\hline Ag Production & 3.8 & 0.5 & 8.4 & 0.8 & 1.0 & 1.1 & 0.2 & 0.5 & 0.2 & 1.2 \\
\hline Construction & 2.5 & 0.4 & 1.9 & 3.7 & 1.9 & 1.0 & 0.1 & 0.2 & 0.3 & 0.4 \\
\hline Other Transportation & 1.4 & 1.9 & 0.5 & 0.4 & 0.1 & 0.2 & 2.5 & 0.2 & 0.1 & 0.2 \\
\hline Ag Services & 1.8 & 0.4 & 1.1 & 1.5 & 1.3 & 0.9 & 1.1 & 0.3 & 0.1 & 0.4 \\
\hline Primary Metals MFG & 0.9 & 0.4 & 2.2 & 1.1 & 0.5 & 0.8 & $<0.1$ & 0.2 & 0.6 & 0.3 \\
\hline Electric Light and Power & 0.9 & 0.2 & 0.5 & 0.9 & 5.2 & 0.2 & 0.1 & 0.1 & 0.3 & 0.2 \\
\hline Other Utility/Sanitary Service & 3.5 & 0.4 & 0.8 & 0.4 & 0.8 & 0.4 & 0.1 & 0.3 & 0.4 & 0.2 \\
\hline Automobile and Repair Services & 1.7 & 1.1 & 0.7 & 0.4 & 0.5 & 0.9 & $<0.1$ & 0.7 & 0.5 & 0.2 \\
\hline Justice, Pub Order, \& Safety & 2.6 & 3.0 & 0.1 & 0.2 & 0.1 & 0.1 & 0.4 & 0.4 & 0.1 & 0.1 \\
\hline Stone/Clay/Concrete MFG & 1.2 & 0.3 & 1.2 & 0.6 & 0.6 & 0.5 & $<0.1$ & 0.2 & 0.2 & 0.2 \\
\hline
\end{tabular}

- The selected groupings had the highest rates per 100,000 workers. 
Table US-23. Number and Average Annual Rate* (per 100,000 workers) of Traumatic Occupational Fatalities by Occupation Division, US, 1980-1995.

\begin{tabular}{|l|c|c|}
\hline \multicolumn{1}{|c|}{$\begin{array}{c}\text { OCCUPATION } \\
\text { DIVISION }\end{array}$} & $\begin{array}{c}\text { NUMBER OF } \\
\text { DEATHS }\end{array}$ & $\begin{array}{c}\text { RATE PER } \\
\mathbf{1 0 0 , 0 0 0}\end{array}$ \\
\hline \hline Crafts & 19,296 & 9.2 \\
\hline Transport & 16,259 & 21.6 \\
\hline Farm/For/Fish & 12,381 & 21.9 \\
\hline Laborers & 10,251 & 13.7 \\
\hline Service & 6,653 & 2.8 \\
\hline Sales & 6,367 & 3.0 \\
\hline Exec/Adm/Mgr & 5,778 & 2.7 \\
\hline Mach Operators & 4,523 & 3.5 \\
\hline Prof/Spec & 3,710 & 1.6 \\
\hline Tech/Support & 2,395 & 4.3 \\
\hline Clerical & 1,944 & 0.7 \\
\hline Not Classified & 3,781 & - \\
\hline
\end{tabular}

• Rates not calculated for "unknown" or "not classified" categories. 
Table US-24. Number" and Rate (per 100,000 workers) of Traumatic Occupational Fatalities by Occupation Division and Year, US, 1980-1995.

\begin{tabular}{|c|c|c|c|c|c|c|c|c|c|c|c|c|c|c|c|c|c|}
\hline \multirow{2}{*}{\multicolumn{2}{|c|}{$\begin{array}{l}\text { OCCUPATION } \\
\text { DIVISION }\end{array}$}} & \multicolumn{16}{|c|}{ YEAR OF DEATH } \\
\hline & & \multirow{2}{*}{\begin{tabular}{|l|}
1980 \\
351 \\
\end{tabular}} & \multirow{2}{*}{\begin{tabular}{|l|}
1981 \\
369 \\
\end{tabular}} & \multirow{2}{*}{1982} & \multirow{2}{*}{$\begin{array}{l}1983 \\
352\end{array}$} & \multirow{2}{*}{\begin{tabular}{|l|}
1984 \\
319 \\
\end{tabular}} & \multirow{2}{*}{1985} & \multirow{2}{*}{\begin{tabular}{|l|}
1986 \\
317 \\
\end{tabular}} & \multirow{2}{*}{\begin{tabular}{|l|}
1987 \\
353 \\
\end{tabular}} & \multirow{2}{*}{\begin{tabular}{|l|}
1988 \\
370 \\
\end{tabular}} & \multirow{2}{*}{$\begin{array}{l}1989 \\
340\end{array}$} & \multirow{2}{*}{\begin{tabular}{|l|}
1990 \\
386 \\
\end{tabular}} & \multirow{2}{*}{\begin{tabular}{|l|}
1991 \\
373 \\
\end{tabular}} & \multirow{2}{*}{ 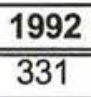 } & \multirow{2}{*}{\begin{tabular}{|l|}
1993 \\
387 \\
\end{tabular}} & \multirow{2}{*}{\begin{tabular}{|l|}
1994 \\
394 \\
\end{tabular}} & \multirow{2}{*}{$\frac{1995}{4223}$} \\
\hline 601 & No. & & & & & & & & & & & & & & & & \\
\hline Ec & Rate & 3.4 & 3.5 & 3.4 & 3.3 & 2.8 & 2.9 & 2.5 & 2.7 & 2.6 & 2.3 & 2.6 & 2.5 & 2.2 & 2.5 & 2.4 & 2.5 \\
\hline \multirow{2}{*}{ Prof/Spec } & No. & 284 & 266 & 239 & 218 & 214 & 244 & 223 & 207 & 202 & 216 & 196 & 237 & 227 & 251 & 240 & 246 \\
\hline & Rate & 2.4 & 2.2 & 1.9 & 1.7 & 1.6 & 1.8 & 1.6 & 1.4 & 1.3 & 1.4 & 1.2 & 1.5 & 1.4 & 1.5 & 1.4 & 1.4 \\
\hline \multirow{2}{*}{ Tech/Support } & No. & 199 & 181 & 150 & 145 & 149 & 171 & 140 & 145 & 139 & 160 & 139 & 138 & 129 & 125 & 144 & 141 \\
\hline & Rate & 7.0 & 6.1 & 5.0 & 4.7 & 4.7 & 5.3 & 4.2 & 4.3 & 3.9 & 4.4 & 3.6 & 3.6 & 3.0 & 3.1 & 3.7 & 3.6 \\
\hline \multirow{2}{*}{ Sales } & No. & 451 & 432 & 414 & 384 & 362 & 390 & 315 & 361 & 359 & 363 & 360 & 402 & 436 & 466 & 469 & 403 \\
\hline & Rate & 4.2 & 3.9 & 3.7 & 3.2 & 2.9 & 3.1 & 2.4 & 2.7 & 2.6 & 2.6 & 2.5 & 2.9 & 3.1 & 3.3 & 3.2 & 2.7 \\
\hline \multirow{2}{*}{ Clerical } & No. & 124 & 134 & 119 & 118 & 106 & 128 & 124 & 124 & 118 & 137 & 118 & 97 & 105 & 106 & 155 & 131 \\
\hline & Rate & 0.7 & 0.8 & 0.7 & 0.7 & 0.6 & 0.7 & 0.7 & 0.7 & 0.6 & 0.7 & 0.6 & 0.5 & 0.6 & 0.6 & 0.8 & 0.7 \\
\hline \multirow{2}{*}{ Servic } & No. & 476 & 447 & 432 & 387 & 388 & 389 & 411 & 427 & 426 & 412 & 389 & 395 & 384 & 413 & 446 & 431 \\
\hline & Rate & 3.6 & 3.4 & 3.2 & 2.8 & 2.7 & 2.7 & 2.8 & 2.8 & 2.8 & 2.6 & 2.5 & 2.5 & 2.4 & 2.5 & 2.6 & 2.5 \\
\hline \multirow{2}{*}{ Farm/For/Fish } & No. & 923 & 889 & 862 & 802 & 840 & 888 & 788 & 841 & 772 & 796 & 696 & 701 & 672 & 665 & 640 & 606 \\
\hline & Rate & 25.4 & 24.1 & 23.0 & 21.7 & 23.3 & 25.6 & 22.9 & 24.0 & 22.5 & 23.3 & 20.4 & 20.3 & 19.4 & 20.0 & 17.6 & 16.6 \\
\hline \multirow{2}{*}{ Crafts } & No. & 1,533 & 1,581 & 1,393 & 1,159 & 1,293 & 1,265 & 1,171 & 1,162 & 1,180 & 1,129 & 1,152 & 1,074 & 1,013 & 1,076 & 1,034 & 1,081 \\
\hline & Rate & 12.5 & 12.9 & 11.8 & 9.4 & 9.9 & 9.5 & 8.7 & 8.6 & 8.6 & 8.2 & 8.4 & 8.2 & 7.7 & 8.1 & 7.7 & 8.0 \\
\hline \multirow{2}{*}{ Mach Operators } & No. & 375 & 358 & 312 & 272 & 297 & 303 & 255 & 285 & 247 & 285 & 268 & 267 & 242 & 230 & 252 & 275 \\
\hline & Rate & 4.2 & 4.1 & 4.0 & 3.5 & 3.7 & 3.9 & 3.2 & 3.6 & 3.0 & 3.5 & 3.3 & 3.5 & 3.2 & 3.1 & 3.2 & 3.5 \\
\hline \multirow{2}{*}{ Transport } & No. & 1,259 & 1,241 & 1,029 & 1,042 & 1,139 & 1,098 & 964 & 955 & 1,054 & 998 & 947 & 900 & 853 & 943 & 915 & 922 \\
\hline & Rate & 28.0 & 28.3 & 24.5 & 24.8 & 25.5 & 24.2 & 21.1 & 20.3 & 21.8 & 20.4 & 19.5 & 18.5 & 17.5 & 18.8 & 17.8 & 17.8 \\
\hline \multirow{2}{*}{ Laborers } & No. & 933 & 777 & 732 & 640 & 711 & 721 & 654 & 706 & 630 & 611 & 598 & 485 & 504 & 470 & 558 & 521 \\
\hline & Rate & 19.9 & 16.6 & 16.3 & 15.4 & 16.1 & 16.2 & 14.0 & 14.8 & 12.9 & 12.5 & 12.3 & 10.6 & 11.1 & 10.2 & 11.2 & 10.4 \\
\hline
\end{tabular}

"Numbers not reported for "unknown" or "not classified" categories. 
Table US-25. Number" of Traumatic Occupational Fatalities by Cause of Death and Occupation Division, US, 1980-1995.

\begin{tabular}{|l|c|c|c|c|c|c|c|c|c|c|c|}
\hline \multirow{2}{*}{ CAUSE OF DEATH } & \multicolumn{9}{|c|}{ OCCUPATION DIVISION } \\
\cline { 2 - 14 } & $\begin{array}{c}\text { EXEC/ } \\
\text { ADM/MGR }\end{array}$ & $\begin{array}{l}\text { PROFI } \\
\text { SPEC }\end{array}$ & $\begin{array}{c}\text { TECH } \\
\text { SUPPORT }\end{array}$ & SALES & CLERCAL & SERVICE & $\begin{array}{c}\text { FARM/ } \\
\text { FOR/FISH }\end{array}$ & CRAFTS & $\begin{array}{c}\text { MACH } \\
\text { OPERATORS }\end{array}$ & TRANSPORT & LABORERS \\
\hline \hline Motor Vehicle & 1,072 & 801 & 291 & 1,223 & 562 & 1,388 & 1,727 & 2,371 & 410 & 9,317 & 1,725 \\
\hline Homicide & 1,703 & 600 & 85 & 3,203 & 594 & 2,340 & 281 & 896 & 285 & 1,082 & 1,085 \\
\hline Machine & 404 & 228 & 84 & 243 & 139 & 274 & 3,932 & 2,404 & 955 & 1,702 & 1,528 \\
\hline Fall & 480 & 322 & 78 & 235 & 146 & 569 & 603 & 4,021 & 512 & 378 & 1,445 \\
\hline Electrocution & 229 & 143 & 91 & 89 & 32 & 197 & 673 & 2,980 & 279 & 459 & 807 \\
\hline Struck by Falling Object & 192 & 84 & 28 & 118 & 44 & 109 & 1,814 & 1,579 & 382 & 615 & 868 \\
\hline Air Transport & 388 & 488 & 1,422 & 171 & 44 & 205 & 112 & 237 & 19 & 36 & 33 \\
\hline Suicide & 468 & 305 & 58 & 500 & 103 & 371 & 231 & 511 & 112 & 170 & 143 \\
\hline Nature/Environment & 66 & 99 & 18 & 60 & 42 & 87 & 682 & 521 & 162 & 241 & 328 \\
\hline Explosion & 137 & 66 & 57 & 73 & 24 & 91 & 93 & 849 & 379 & 180 & 311 \\
\hline Flying Object/Caught In & 68 & 44 & 12 & 42 & 29 & 79 & 350 & 554 & 237 & 301 & 376 \\
\hline Water Transport & 31 & 89 & 23 & 21 & 7 & 44 & 691 & 151 & 52 & 531 & 119 \\
\hline Suffocation & 84 & 44 & 10 & 45 & 11 & 62 & 230 & 391 & 99 & 159 & 495 \\
\hline Fire & 106 & 47 & 26 & 68 & 28 & 219 & 123 & 422 & 203 & 104 & 174 \\
\hline Poisoning & 87 & 89 & 37 & 55 & 20 & 126 & 133 & 408 & 122 & 125 & 169 \\
\hline Drowning & 56 & 104 & 13 & 23 & 17 & 126 & 326 & 204 & 58 & 157 & 199 \\
\hline Rail Transport & 16 & 14 & 7 & 3 & 17 & 15 & 14 & 94 & 34 & 345 & 91 \\
\hline Other & 157 & 116 & 39 & 140 & 63 & 275 & 310 & 600 & 205 & 270 & 293 \\
\hline
\end{tabular}

"Numbers not reported for "unknown" or "not classified" categories. 
Table US-26. Average Annual Rate (per 100,000 workers) of Traumatic Occupational Fatalities by Cause of Death and Occupation Division, US, 1980-1995.

\begin{tabular}{|c|c|c|c|c|c|c|c|c|c|c|c|}
\hline \multirow[b]{2}{*}{ CAUSE OF DEATH } & \multicolumn{11}{|c|}{ OCCUPATION DIVISION } \\
\hline & $\begin{array}{c}\text { EXEC/ } \\
\text { ADM/MGR }\end{array}$ & $\begin{array}{l}\text { PROFI } \\
\text { SPEC }\end{array}$ & $\begin{array}{c}\text { TECH } \\
\text { SUPPORT }\end{array}$ & SALES & CLERICAL & SERVICE & $\begin{array}{c}\text { FARMII } \\
\text { FOR/FISH }\end{array}$ & CRAFTS & $\begin{array}{c}\text { MACH } \\
\text { OPERATORS }\end{array}$ & TRANSPORT & LABORERS \\
\hline Motor Vehicle & 0.5 & 0.3 & 0.5 & 0.6 & 0.2 & 0.6 & 3.1 & 1.1 & 0.3 & 12.4 & 2.3 \\
\hline Homicide & 0.8 & 0.3 & 0.2 & 1.5 & 0.2 & 1.0 & 0.5 & 0.4 & 0.2 & 1.4 & 1.5 \\
\hline Machine & 0.2 & 0.1 & 0.2 & 0.1 & $<0.1$ & 0.1 & 7.0 & 1.1 & 0.7 & 2.3 & 2.0 \\
\hline Fall & 0.2 & 0.1 & 0.1 & 0.1 & 0.1 & 0.2 & 1.1 & 1.9 & 0.4 & 0.5 & 1.9 \\
\hline Electrocution & 0.1 & 0.1 & 0.2 & $<0.1$ & $<0.1$ & 0.1 & 1.2 & 1.4 & 0.2 & 0.6 & 1.1 \\
\hline Struck by Falling Object & 0.1 & $<0.1$ & 0.1 & 0.1 & $<0.1$ & $<0.1$ & 3.2 & 0.8 & 0.3 & 0.8 & 1.2 \\
\hline Air Transport & 0.2 & 0.2 & 2.5 & 0.1 & $<0.1$ & 0.1 & 0.2 & 0.1 & $<0.1$ & $<0.1$ & $<0.1$ \\
\hline Suicide & 0.2 & 0.1 & 0.1 & 0.2 & $<0.1$ & 0.2 & 0.4 & 0.2 & 0.1 & 0.2 & 0.2 \\
\hline Nature/Environment & $<0.1$ & $<0.1$ & $<0.1$ & $<0.1$ & $<0.1$ & $<0.1$ & 1.2 & 0.2 & 0.1 & 0.3 & 0.4 \\
\hline Explosion & 0.1 & $<0.1$ & 0.1 & $<0.1$ & $<0.1$ & $<0.1$ & 0.2 & 0.4 & 0.3 & 0.2 & 0.4 \\
\hline Flying Object/Caught In & $<0.1$ & $<0.1$ & $<0.1$ & $<0.1$ & $<0.1$ & $<0.1$ & 0.6 & 0.3 & 0.2 & 0.4 & 0.5 \\
\hline Water Transport & $<0.1$ & $<0.1$ & $<0.1$ & $<0.1$ & $<0.1$ & $<0.1$ & 1.2 & 0.1 & $<0.1$ & 0.7 & 0.2 \\
\hline Suffocation & $<0.1$ & $<0.1$ & $<0.1$ & $<0.1$ & $<0.1$ & $<0.1$ & 0.4 & 0.2 & 0.1 & 0.2 & 0.7 \\
\hline Fire & $<0.1$ & $<0.1$ & $<0.1$ & $<0.1$ & $<0.1$ & 0.1 & 0.2 & 0.2 & 0.2 & 0.1 & 0.2 \\
\hline Poisoning & $<0.1$ & $<0.1$ & 0.1 & $<0.1$ & $<0.1$ & 0.1 & 0.2 & 0.2 & 0.1 & 0.2 & 0.2 \\
\hline Drowning & $<0.1$ & $<0.1$ & $<0.1$ & $<0.1$ & $<0.1$ & 0.1 & 0.6 & 0.1 & $<0.1$ & 0.2 & 0.3 \\
\hline Rail Transport & $<0.1$ & $<0.1$ & $<0.1$ & $<0.1$ & $<0.1$ & $<0.1$ & $<0.1$ & $<0.1$ & $<0.1$ & 0.5 & 0.1 \\
\hline Other & 0.1 & $<0.1$ & 0.1 & 0.1 & $<0.1$ & 0.1 & 0.5 & 0.3 & 0.2 & 0.4 & 0.4 \\
\hline
\end{tabular}


Table US-27. Number ${ }^{*}$ and Average Annual Rate ${ }^{\ddagger}$ (per 100,000 workers) of Traumatic Occupational Fatalities by Occupation Division and Age Group, US, 1983-1995.

\begin{tabular}{|l|l|c|c|c|c|c|c|c|c|}
\hline \multicolumn{2}{|c|}{$\begin{array}{c}\text { OCCUPATION } \\
\text { DIVISION }\end{array}$} & \multicolumn{7}{|c|}{ AGE GROUP (IN YEARS) } \\
\cline { 2 - 10 } & $\mathbf{1 6 - 1 7}$ & $\mathbf{1 8 - 1 9}$ & $\mathbf{2 0 - 2 4}$ & $\mathbf{2 5 - 3 4}$ & $\mathbf{3 5 - 4 4}$ & $\mathbf{4 5 - 5 4}$ & $\mathbf{5 5 - 6 4}$ & $\mathbf{6 5 +}$ \\
\hline \hline \multirow{2}{*}{ Exec/Adm/Mgr } & No. & 5 & 31 & 195 & 932 & 1,140 & 1,089 & 859 & 448 \\
\cline { 2 - 10 } & Rate & 2.8 & 3.5 & 1.8 & 1.9 & 2.0 & 2.7 & 4.0 & 8.3 \\
\hline \multirow{2}{*}{ Prof/Spec } & No. & 4 & 22 & 181 & 689 & 741 & 552 & 447 & 285 \\
\cline { 2 - 10 } & Rate & 0.8 & 1.8 & 1.4 & 1.2 & 1.2 & 1.4 & 2.3 & 5.3 \\
\hline \multirow{2}{*}{ Tech/Support } & No. & - & 11 & 156 & 589 & 532 & 352 & 182 & 43 \\
\cline { 2 - 10 } & Rate & - & 2.0 & 2.7 & 3.3 & 4.1 & 5.1 & 6.3 & 9.2 \\
\hline \multirow{2}{*}{ Sales } & No. & 16 & 85 & 358 & 988 & 1,167 & 1,004 & 869 & 580 \\
\cline { 2 - 10 } & Rate & 0.2 & 0.8 & 1.5 & 2.2 & 3.0 & 3.6 & 4.8 & 8.8 \\
\hline \multirow{2}{*}{ Clerical } & No. & 7 & 36 & 173 & 388 & 350 & 268 & 211 & 133 \\
\cline { 2 - 10 } & Rate & 0.3 & 0.5 & 0.5 & 0.6 & 0.6 & 0.7 & 0.9 & 2.3 \\
\hline \multirow{2}{*}{ Service } & No. & 13 & 101 & 594 & 1,586 & 1,243 & 843 & 609 & 308 \\
\cline { 2 - 10 } & Rate & 0.1 & 0.8 & 1.9 & 3.1 & 3.1 & 3.0 & 3.1 & 4.1 \\
\hline \multirow{2}{*}{ Farm/For/Fish } & No. & 54 & 237 & 872 & 1,973 & 1,676 & 1,436 & 1,513 & 1,931 \\
\cline { 2 - 10 } & Rate & 2.4 & 10.5 & 16.1 & 18.5 & 19.3 & 21.8 & 25.2 & 47.6 \\
\hline \multirow{2}{*}{ Crafts } & No. & 22 & 230 & 1,437 & 4,274 & 3,652 & 2,560 & 1,879 & 730 \\
\cline { 2 - 10 } & Rate & 2.6 & 6.7 & 7.8 & 7.8 & 7.9 & 8.5 & 11.0 & 24.9 \\
\hline \multirow{2}{*}{ Mach Operators } & No. & 7 & 82 & 379 & 951 & 832 & 593 & 460 & 174 \\
\cline { 2 - 10 } & Rate & 1.1 & 2.8 & 2.9 & 3.0 & 3.3 & 3.4 & 4.5 & 11.7 \\
\hline \multirow{2}{*}{ Transport } & No. & 14 & 162 & 1,008 & 3,519 & 3,248 & 2,535 & 1,774 & 460 \\
\cline { 2 - 10 } & Rate & 3.7 & 11.7 & 16.0 & 19.3 & 19.9 & 22.2 & 26.0 & 31.5 \\
\hline \multirow{2}{*}{ Laborers } & No. & 55 & 382 & 1,269 & 2,399 & 1,598 & 1,107 & 757 & 230 \\
\cline { 2 - 9 } & Rate & 1.2 & 6.1 & 10.0 & 14.5 & 15.6 & 17.8 & 19.8 & 23.6 \\
\hline
\end{tabular}

Numbers not reported for cells with less than 3 deaths.

'Numbers not reported for "unknown" or "not classified" categories.

${ }^{\ddagger}$ Rates not calculated for categories with less than 3 deaths or less than 20,000 employed. 


\begin{tabular}{|l|c|c|}
\hline \multicolumn{1}{|c|}{ DETAILED OCCUPATION } & $\begin{array}{c}\text { NO. OF } \\
\text { DEATHS }\end{array}$ & RATE \\
\hline \hline Exec/Adm/Mgr & & \\
\hline Officials \& Administrators, Public Admin & 160 & 2.1 \\
\hline Other Executive, Admin \& Managerial & 4,037 & 3.2 \\
\hline Management Related Occupations & 504 & 1.0 \\
\hline Prof/Spec & & \\
\hline Engineers & 844 & 3.3 \\
\hline Mathematical and Computer Scientists & 56 & 0.5 \\
\hline Natural Scientists & 204 & 3.6 \\
\hline Health Diagnosing Occupations & 193 & 1.8 \\
\hline Health Assessment and Treatment Occupations & 237 & 0.8 \\
\hline Teachers, College and University & 68 & 0.7 \\
\hline Teachers, Except College and University & 388 & 0.8 \\
\hline Lawyers and Judges & 147 & 1.5 \\
\hline Other Professional Specialty Occupations & 784 & 1.6 \\
\hline Tech/Support & & \\
\hline Health Technologists and Technicians & 119 & 0.7 \\
\hline Engineering and Science Technicians & 462 & 3.1 \\
\hline Technicians, Exc Health/Engineering/Science & 1,284 & 8.5 \\
\hline Sales & & \\
\hline Supervisors and Proprietors, Sales Occupations & 2,834 & 5.8 \\
\hline Sales Reps, Finance and Business Services & 405 & 1.4 \\
\hline Sales Reps, Commodities, Except Retail & 359 & 1.8 \\
\hline Sales Workers, Retail \& Personal Services & 1,456 & 1.8 \\
\hline Sales Related Occupations & 16 & 1.7 \\
\hline Clerical & & \\
\hline Supervisors, Administrative Support & 74 & 0.8 \\
\hline Computer Equipment Operators & 27 & 0.3 \\
\hline Secretaries, Stenographers, and Typists & 184 & 0.3 \\
\hline Financial Records Processing & 84 & 0.3 \\
\hline Mail and Message Distribution & 318 & 2.7 \\
\hline Other Admin. Support, Including Clerical & 880 & 0.8 \\
\hline & & \\
\hline & & \\
\hline
\end{tabular}

\begin{tabular}{|l|c|c|}
\hline \multicolumn{1}{|c|}{ DETAILED OCCUPATION } & $\begin{array}{c}\text { NO. OF } \\
\text { DEATHS }\end{array}$ & RATE \\
\hline \hline Service & & \\
\hline Private Household Service Occupations & 92 & 0.8 \\
\hline Protective Service & 2,765 & 10.8 \\
\hline Food Service & 652 & 0.9 \\
\hline Health Service & 129 & 0.5 \\
\hline Cleaning and Building Service & 1,331 & 3.5 \\
\hline Personal Service & 329 & 1.1 \\
\hline Farm/For/Fish & & \\
\hline Farm Operators and Managers & 4,646 & 27.1 \\
\hline Farm Workers and Related Occupations & 2,439 & 9.3 \\
\hline Forestry and Fishing Occupations & 2,622 & 112.4 \\
\hline Crafts & & \\
\hline Mechanics and Repairers & 3,595 & 6.3 \\
\hline Construction Trades & 7,691 & 12.0 \\
\hline Other Precision Production, Craft, and Repair & 3,503 & 6.7 \\
\hline Mach Operators & & \\
\hline Machine Operators/Tenders, Except Precision & 2,188 & 3.2 \\
\hline Fabricators, Assemblers, Inspectors, Samplers & 1,290 & 3.7 \\
\hline Transport & & \\
\hline Motor Vehicle Operators & 9,561 & 20.7 \\
\hline Other Transport and Material Moving Occ & 3,169 & 19.8 \\
\hline Laborers & & \\
\hline Construction Laborers & 3,726 & 39.5 \\
\hline Freight, Stock, \& Materials Handlers & 998 & 4.4 \\
\hline Other Handlers,Equip. Cleaner,Helper,Laborer & 3,085 & 10.5 \\
\hline Other or Not Classified & 2,621 & - \\
\hline & & \\
\hline
\end{tabular}

'Rates not calculated for "unknown" or "not classified" categories. 
Table US-29. Number and Rate (per 100,000 workers) of Traumatic Occupational Fatalities by Selected Detailed Occupation Groupings" and Year, US, 1983-1995.

\begin{tabular}{|c|c|c|c|c|c|c|c|c|c|c|c|c|c|c|}
\hline \multirow{2}{*}{\multicolumn{2}{|c|}{ DETAILED OCCUPATION }} & \multicolumn{13}{|c|}{ YEAR OF DEATH } \\
\hline & & \multirow{2}{*}{\begin{tabular}{|c|}
1983 \\
199 \\
\end{tabular}} & \multirow{2}{*}{$\begin{array}{c}1984 \\
211 \\
\end{array}$} & \multirow{2}{*}{$\begin{array}{c}1985 \\
236 \\
\end{array}$} & \multirow{2}{*}{\begin{tabular}{|c|}
1986 \\
218 \\
\end{tabular}} & \multirow{2}{*}{\begin{tabular}{|c|}
1987 \\
220
\end{tabular}} & \multirow{2}{*}{\begin{tabular}{|l|}
1988 \\
217
\end{tabular}} & \multirow{2}{*}{\begin{tabular}{|c|}
1989 \\
263
\end{tabular}} & \multirow{2}{*}{\begin{tabular}{|l|}
1990 \\
203
\end{tabular}} & \multirow{2}{*}{$\begin{array}{c}1991 \\
200\end{array}$} & \multirow{2}{*}{\begin{tabular}{|c|}
1992 \\
190
\end{tabular}} & \multirow{2}{*}{\begin{tabular}{|c|}
1993 \\
159
\end{tabular}} & \multirow{2}{*}{$\begin{array}{l}1994 \\
164\end{array}$} & \multirow{2}{*}{$\begin{array}{l}1995 \\
142\end{array}$} \\
\hline Forestry and Fishing & No. & & & & & & & & & & & & & \\
\hline Occu & Rate & 109.1 & 130.1 & 143.3 & 114.5 & 125.5 & 127.2 & 148.2 & 103.3 & 113.5 & 109.7 & 81.8 & 89.6 & 76.5 \\
\hline \multirow{2}{*}{ Construction Laborers } & No. & 288 & 337 & 344 & 318 & 358 & 310 & 306 & 283 & 204 & 240 & 210 & 269 & 259 \\
\hline & Rate & 48.6 & 50.3 & 49.9 & 42.7 & 46.2 & 38.7 & 40.5 & 35.5 & 28.3 & 35.5 & 30.8 & 36.4 & 33.2 \\
\hline \multirow{2}{*}{$\begin{array}{l}\text { Farm Operators and } \\
\text { Managers }\end{array}$} & No. & 396 & 421 & 435 & 394 & 422 & 375 & 339 & 308 & 320 & 326 & 320 & 297 & 293 \\
\hline & Rate & 27.3 & 29.2 & 32.1 & 29.4 & 32.2 & 29.2 & 26.7 & 25.4 & 26.0 & 26.8 & 27.6 & 20.4 & 20.2 \\
\hline \multirow{2}{*}{ Motor Vehicle Operators } & No. & 749 & 846 & 833 & 735 & 691 & 824 & 737 & 678 & 672 & 641 & 706 & 707 & 742 \\
\hline & Rate & 24.9 & 26.4 & 25.2 & 21.7 & 19.8 & 22.9 & 20.5 & 18.8 & 18.1 & 17.2 & 18.3 & 18.3 & 19.0 \\
\hline \multirow{2}{*}{$\begin{array}{l}\text { Other Transport and } \\
\text { Material Movers }\end{array}$} & No. & 293 & 293 & 265 & 229 & 264 & 230 & 261 & 269 & 228 & 212 & 237 & 208 & 180 \\
\hline & Rate & 23.8 & 23.1 & 21.5 & 19.3 & 21.6 & 18.6 & 20.4 & 21.1 & 19.1 & 18.0 & 19.8 & 16.5 & 14.2 \\
\hline \multirow{2}{*}{ Construction Trades } & No. & 565 & 636 & 653 & 620 & 633 & 634 & 612 & 608 & 550 & 518 & 513 & 563 & 586 \\
\hline & Rate & 13.1 & 13.8 & 13.7 & 12.5 & 12.6 & 12.4 & 11.9 & 11.7 & 11.3 & 10.7 & 10.1 & 11.2 & 11.5 \\
\hline \multirow{2}{*}{ Protective Service } & No. & 190 & 214 & 198 & 207 & 206 & 235 & 218 & 199 & 194 & 210 & 226 & 227 & 241 \\
\hline & Rate & 11.4 & 12.7 & 11.5 & 11.6 & 10.8 & 12.1 & 11.2 & 9.9 & 9.3 & 9.9 & 10.5 & 10.1 & 10.8 \\
\hline \multirow{2}{*}{$\begin{array}{l}\text { Other Handler, Cleaner, } \\
\text { Helper, Laborer }\end{array}$} & No. & 279 & 293 & 297 & 265 & 278 & 242 & 214 & 242 & 190 & 202 & 197 & 204 & 182 \\
\hline & Rate & 13.6 & 13.4 & 13.7 & 11.9 & 12.0 & 10.4 & 8.9 & 10.0 & 8.3 & 9.1 & 9.1 & 9.2 & 8.0 \\
\hline \multirow{2}{*}{$\begin{array}{l}\text { Farm Workers and } \\
\text { Related Occ }\end{array}$} & No. & 207 & 208 & 217 & 176 & 199 & 180 & 194 & 185 & 181 & 156 & 186 & 179 & 171 \\
\hline & Rate & 9.9 & 10.3 & 11.1 & 9.2 & 9.8 & 9.1 & 9.8 & 9.0 & 8.5 & 7.3 & 9.1 & 9.0 & 8.4 \\
\hline \multirow{2}{*}{$\begin{array}{l}\text { Technicians, Exc Health/ } \\
\text { Eng/Science }\end{array}$} & No. & 98 & 104 & 131 & 108 & 108 & 98 & 117 & 87 & 77 & 84 & 86 & 95 & 91 \\
\hline & Rate & 10.7 & 10.6 & 12.7 & 9.9 & 9.8 & 8.6 & 9.6 & 6.6 & 6.3 & 5.3 & 6.3 & 8.7 & 8.3 \\
\hline \multirow{2}{*}{$\begin{array}{l}\text { Other Prec } \\
\text { Production/Craft/Repair }\end{array}$} & No. & 312 & 388 & 349 & 281 & 255 & 267 & 251 & 269 & 254 & 227 & 225 & 212 & 213 \\
\hline & Rate & 8.0 & 9.5 & 8.5 & 6.8 & 6.2 & 6.5 & 6.1 & 6.6 & 6.4 & 5.8 & 5.7 & 5.2 & 5.3 \\
\hline \multirow{2}{*}{ Mechanics and Repairers } & No. & 282 & 269 & 263 & 270 & 274 & 279 & 266 & 275 & 270 & 268 & 338 & 259 & 282 \\
\hline & Rate & 6.8 & 6.2 & 5.9 & 6.2 & 6.2 & 6.3 & 5.9 & 6.2 & 6.1 & 6.0 & 7.6 & 5.9 & 6.4 \\
\hline
\end{tabular}

- The selected groupings had the highest rates per 100,000 workers. 
Table US-30. Number and Average Annual Rate (per 100,000 workers) of Traumatic Occupational Fatalities by Selected Detailed Occupation Groupings* and Cause of Death, US, 1983-1995.

\begin{tabular}{|c|c|c|c|c|c|c|c|c|c|c|c|}
\hline \multirow{2}{*}{\multicolumn{2}{|c|}{ DETAILED OCCUPATION }} & \multicolumn{10}{|c|}{ CAUSE OF DEATH } \\
\hline & & \multirow{2}{*}{$\begin{array}{c}\begin{array}{c}\text { MOTOR } \\
\text { VEHICLE }\end{array} \\
140 \\
\end{array}$} & \multirow{2}{*}{\begin{tabular}{|c|} 
HOMICIDE \\
24 \\
\end{tabular}} & \multirow{2}{*}{\begin{tabular}{|c|} 
MACHINE \\
271
\end{tabular}} & \multirow{2}{*}{\begin{tabular}{|c} 
FALL \\
57
\end{tabular}} & \multirow{2}{*}{\begin{tabular}{|c|}
$\begin{array}{c}\text { ELECTRO- } \\
\text { CUTION }\end{array}$ \\
43
\end{tabular}} & \multirow{2}{*}{\begin{tabular}{|c|}
$\begin{array}{c}\text { STRUCK } \\
\text { BY } \\
\text { FALLING }\end{array}$ \\
993 \\
\end{tabular}} & \multirow{2}{*}{\begin{tabular}{|c|c}
$\begin{array}{c}\text { AIR } \\
\text { TRANS }\end{array}$ \\
23 \\
\end{tabular}} & \multirow{2}{*}{\begin{tabular}{|c|} 
SUICIDE \\
18
\end{tabular}} & \multirow{2}{*}{\begin{tabular}{|c} 
EXPLOSION \\
5
\end{tabular}} & \multirow{2}{*}{\begin{tabular}{|c}
$\begin{array}{l}\text { NATURE } \\
\text { ENVIRON }\end{array}$ \\
110 \\
\end{tabular}} \\
\hline Forestry and Fishing & No. & & & & & & & & & & \\
\hline Occupations & Rate & 6.0 & 1.0 & 11.6 & 2.4 & 1.8 & 42.6 & 1.0 & 0.8 & 0.2 & 4.7 \\
\hline \multirow{2}{*}{ Construction Laborers } & No. & 742 & 106 & 479 & 806 & 372 & 361 & 10 & 40 & 59 & 117 \\
\hline & Rate & 7.9 & 1.1 & 5.1 & 8.6 & 3.9 & 3.8 & 0.1 & 0.4 & 0.6 & 1.2 \\
\hline \multirow{2}{*}{$\begin{array}{l}\text { Farm Operators and } \\
\text { Managers }\end{array}$} & No. & 695 & 71 & 2,161 & 219 & 182 & 294 & 45 & 120 & 42 & 278 \\
\hline & Rate & 4.0 & 0.4 & 12.6 & 1.3 & 1.1 & 1.7 & 0.3 & 0.7 & 0.2 & 1.6 \\
\hline \multirow{2}{*}{ Motor Vehicle Operators } & No. & 6,841 & 837 & 357 & 170 & 217 & 315 & 15 & 95 & 77 & 102 \\
\hline & Rate & 14.8 & 1.8 & 0.8 & 0.4 & 0.5 & 0.7 & $<0.1$ & 0.2 & 0.2 & 0.2 \\
\hline \multirow{2}{*}{$\begin{array}{l}\text { Other Transport and } \\
\text { Material Movers }\end{array}$} & No. & 464 & 50 & 964 & 119 & 123 & 191 & 10 & 53 & 47 & 86 \\
\hline & Rate & 2.9 & 0.3 & 6.0 & 0.7 & 0.8 & 1.2 & 0.1 & 0.3 & 0.3 & 0.5 \\
\hline \multirow{2}{*}{ Construction Trades } & No. & 795 & 195 & 601 & 2,478 & 1,688 & 448 & 48 & 149 & 163 & 162 \\
\hline & Rate & 1.2 & 0.3 & 0.9 & 3.9 & 2.6 & 0.7 & 0.1 & 0.2 & 0.3 & 0.3 \\
\hline \multirow{2}{*}{ Protective Service } & No. & 803 & 1,141 & 35 & 82 & 30 & 27 & 98 & 151 & 19 & 30 \\
\hline & Rate & 3.2 & 4.5 & 0.1 & 0.3 & 0.1 & 0.1 & 0.4 & 0.6 & 0.1 & 0.1 \\
\hline \multirow{2}{*}{$\begin{array}{l}\text { Other Handler, Cleaner, } \\
\text { Helper, Laborer }\end{array}$} & No. & 440 & 352 & 547 & 283 & 203 & 249 & 5 & 57 & 163 & 110 \\
\hline & Rate & 1.5 & 1.2 & 1.9 & 1.0 & 0.7 & 0.9 & $<0.1$ & 0.2 & 0.6 & 0.4 \\
\hline \multirow{2}{*}{$\begin{array}{l}\text { Farm Workers and } \\
\text { Related Occ }\end{array}$} & No. & 558 & 117 & 539 & 201 & 263 & 182 & 15 & 53 & 21 & 158 \\
\hline & Rate & 2.1 & 0.4 & 2.0 & 0.8 & 1.0 & 0.7 & 0.1 & 0.2 & 0.1 & 0.6 \\
\hline \multirow{2}{*}{$\begin{array}{l}\text { Technicians, Exc Health/ } \\
\text { Eng/Science }\end{array}$} & No. & 51 & 24 & 21 & 18 & 12 & 5 & 1,067 & 17 & 9 & 6 \\
\hline & \begin{tabular}{|l|} 
Rate \\
\end{tabular} & 0.3 & 0.2 & 0.1 & 0.1 & 0.1 & $<0.1$ & 7.0 & 0.1 & 0.1 & $<0.1$ \\
\hline \multirow{2}{*}{$\begin{array}{l}\text { Other Prec } \\
\text { Production/Craft/Repair }\end{array}$} & No. & 403 & 239 & 697 & 326 & 244 & 380 & 32 & 111 & 259 & 146 \\
\hline & Rate & 0.8 & 0.5 & 1.3 & 0.6 & 0.5 & 0.7 & 0.1 & 0.2 & 0.5 & 0.3 \\
\hline \multirow{2}{*}{ Mechanics and Repairers } & No. & 663 & 250 & 512 & 313 & 335 & 343 & 92 & 173 & 201 & 108 \\
\hline & Rate & 1.2 & 0.4 & 0.9 & 0.5 & 0.6 & 0.6 & 0.2 & 0.3 & 0.4 & 0.2 \\
\hline
\end{tabular}

- The selected groupings had the highest rates per 100,000 workers. 


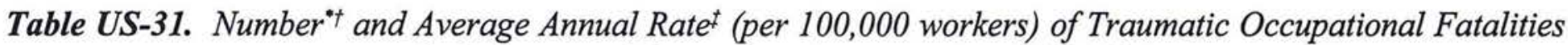
by Industry and Occupation Division, US, 1983-1995.

\begin{tabular}{|c|c|c|c|c|c|c|c|c|c|c|c|c|}
\hline \multirow{2}{*}{\multicolumn{2}{|c|}{ INDUSTRY DIVISION }} & \multicolumn{11}{|c|}{ OCCUPATION DIVISION } \\
\hline & & \multirow{2}{*}{\begin{tabular}{|c|}
$\begin{array}{c}\text { EXEC/ADM/ } \\
\text { MGR }\end{array}$ \\
49 \\
\end{tabular}} & \multirow{2}{*}{\begin{tabular}{|c|}
$\begin{array}{c}\text { PROFI } \\
\text { SPEC }\end{array}$ \\
127 \\
\end{tabular}} & \multirow{2}{*}{\begin{tabular}{|c|}
$\begin{array}{c}\text { TECH/ } \\
\text { SUPPORT }\end{array}$ \\
138 \\
\end{tabular}} & \multirow{2}{*}{\begin{tabular}{|c|} 
SALES \\
17 \\
\end{tabular}} & \multirow{2}{*}{\begin{tabular}{|c|} 
CLERICAL \\
11 \\
\end{tabular}} & \multirow{2}{*}{\begin{tabular}{|c|} 
SERVICE \\
56 \\
\end{tabular}} & \multirow{2}{*}{\begin{tabular}{|c|}
$\begin{array}{c}\text { FARM/FOR/ } \\
\text { FSH }\end{array}$ \\
7,627 \\
\end{tabular}} & \multirow{2}{*}{\begin{tabular}{|c} 
CRAFTS \\
59 \\
\end{tabular}} & \multirow{2}{*}{$\begin{array}{c}\begin{array}{c}\text { MACH } \\
\text { OPER- } \\
\text { ATORS }\end{array} \\
32 \\
\end{array}$} & \multirow{2}{*}{\begin{tabular}{|c|}
$\begin{array}{c}\text { TRANS- } \\
\text { PORT }\end{array}$ \\
201 \\
\end{tabular}} & \multirow{2}{*}{\begin{tabular}{|c|} 
LABORERS \\
36 \\
\end{tabular}} \\
\hline$\Delta a /$ For/Fich & No. & & & & & & & & & & & \\
\hline 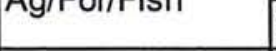 & Rate & 4.2 & 10.2 & 29.6 & 7.1 & 0.7 & 15.1 & 20.1 & 9.7 & 19.8 & 31.2 & 12.5 \\
\hline \multirow{2}{*}{ Mining } & No. & 107 & 76 & 43 & 8 & 13 & 18 & 5 & 1,624 & 81 & 512 & 193 \\
\hline & Rate & 6.9 & 7.4 & 10.1 & 6.5 & 1.1 & 15.0 & - & 49.3 & 23.3 & 31.5 & 46.4 \\
\hline \multirow{2}{*}{ Construction } & No. & 707 & 183 & 77 & 47 & 43 & 46 & 30 & 6,639 & 355 & 1,615 & 3,752 \\
\hline & Rate & 5.8 & 10.1 & 10.5 & 5.1 & 0.8 & 10.7 & 11.4 & 12.2 & 28.6 & 24.7 & 35.3 \\
\hline \multirow{2}{*}{ Manufacturing } & No. & 623 & 307 & 242 & 289 & 201 & 336 & 1,771 & 2,257 & 2,311 & 1,250 & 1,136 \\
\hline & Rate & 2.0 & 1.4 & 2.6 & 3.0 & 0.7 & 7.4 & 147.1 & 4.4 & 2.7 & 12.2 & 8.0 \\
\hline \multirow{2}{*}{ Trans/Comm/PU } & No. & 464 & 244 & 905 & 86 & 442 & 198 & 21 & 1,608 & 148 & 7,235 & 741 \\
\hline & Rate & 3.9 & 4.1 & 24.7 & 2.3 & 1.6 & 6.0 & 11.4 & 9.8 & 9.7 & 31.1 & 12.0 \\
\hline \multirow{2}{*}{ Wholesale Trade } & No. & 133 & 20 & 10 & 611 & 52 & 32 & 15 & 190 & 76 & 726 & 296 \\
\hline & Rate & 2.0 & 1.8 & 1.8 & 2.6 & 0.5 & 6.0 & 4.7 & 4.7 & 4.2 & 11.9 & 6.4 \\
\hline \multirow{2}{*}{ Retail Trade } & No. & 879 & 78 & 12 & 3,372 & 140 & 686 & 22 & 322 & 21 & 468 & 768 \\
\hline & Rate & 4.5 & 1.7 & 1.1 & 3.2 & 0.7 & 1.2 & 7.1 & 2.2 & 0.9 & 7.4 & 4.1 \\
\hline \multirow{2}{*}{ Finance/Insur/RE } & No. & 280 & 17 & 8 & 385 & 131 & 121 & 28 & 30 & - & 16 & 9 \\
\hline & Rate & 1.1 & 0.6 & 0.4 & 1.6 & 0.3 & 3.3 & 3.4 & 1.5 & - & 8.6 & 3.2 \\
\hline \multirow{2}{*}{ Services } & No. & 1,044 & 1,638 & 267 & 202 & 301 & 1,694 & 131 & 1,622 & 311 & 337 & 442 \\
\hline & Rate & 1.8 & 1.1 & 1.0 & 1.8 & 0.4 & 1.5 & 3.1 & 6.7 & 3.1 & 5.1 & 8.4 \\
\hline \multirow{2}{*}{ Public Admin } & No. & 260 & 202 & 129 & 7 & 178 & 2,015 & 29 & 221 & 48 & 135 & 116 \\
\hline & Rate & 1.7 & 2.0 & 4.3 & 2.2 & 1.0 & 11.5 & 4.6 & 7.1 & 10.1 & 18.2 & 19.8 \\
\hline
\end{tabular}

Numbers not reported for cells with less than 3 deaths.

'Numbers not reported for "unknown" or "not classified" categories.

${ }^{\ddagger}$ Rates not calculated for categories with less than 3 deaths or less than 20,000 employed. 


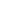




\title{
Appendix II
}

\section{Abbreviations for Bureau of Census (BOC) Industry and Occupation Divisions}

\author{
Industry \\ Abbreviation \\ Description (BOC) \\ $\mathrm{Ag} /$ For/Fish \\ Mining \\ Agriculture/Forestry/Fisheries \\ Construction \\ Mining (includes oil and gas extraction) \\ Manufacturing \\ Construction \\ Manufacturing \\ Trans/Comm/PU \\ Transportation/Communications/Public Utilities \\ Wholesale Trade \\ Wholesale Trade \\ Retail Trade \\ Retail Trade \\ Finance/Insur/RE \\ Services \\ Finance/Insurance/Real Estate \\ Public Admin \\ Services \\ Public Administration
}

\section{Occupation}

Abbreviation

\section{Description (BOC)}

Exec/Adm/Mgr

Prof/Spec

Tech/Support

Sales

Clerical

Service

Farm/For/Fish

Crafts

Mach Operators

Transport

Laborers
Executives/Administrators/Managers

Professional Specialties

Technicians/Related Support

Sales

Clerical

Service

Farming/Forestry/Fishing

Precision Production/Craft/Repair

Machine Operators/Assemblers/Inspectors

Transportation/Material Movers

Handlers/Equipment Cleaners/Helpers/Laborers 



\section{Appendix II}

\section{Detailed Bureau of the Census (BOC) Industry Groupings*}

\section{BOC Industry Codes ${ }^{\dagger}$}

010-011

012-030 (020-021)

031-032 (030-031)

042

040-041, 050

060

$100-122$

$132-150$

$151-152$

$160-162$

171-172

180-192, 200-201, 210-212

230-241

242

250-262

270-280

281-300

301

310-332

340-350

351

352

$360=370$

371-381

390

$130,220-222,391-392$

410-411

400-402, 412-432

441

440,442

$450(460)$

451-472 (461-472)

500-571

601-611

612-622

623-630 (630-631)

641
Industry Description

Ag Production

Ag Services

Forestry \& Fisheries

Oil and Gas Extraction

Metal/Coal/Nonmetal Mining

Construction

Food \& Kindred Prod MFG

Textile Mill Prod MFG

Apparel \& Other Textile Pr MFG

Paper \& Allied Products MFG

Printing/Publishing/AlliedMFG

Chemical/Petroleum/Rubber MFG

Lumber \& Wood MFG

Furniture MFG

Stone/Clay/Concrete MFG

Primary Metals MFG

Fabricated Metals MFG

NS Metal Ind

Mach, Ex Elect MFG

Elect Mach, Equip Supplies MFG

Motor Vehicles Equip

Aircraft \& Parts MFG

Other Transport Equip MFG

Prof \& Photo Equip/Watches MFG

Toys/Amusement/Sporting Goods

Misc \& NEC MFG Industries

Trucking/Warehousing/Storage

Other Transportation

Telephone Communications

Other Communications

Electric Light and Power

Other Utility/Sanitary Service

Wholesale Trade

Food Stores

Motor Veh/Auto Supply Dealer

Apparel \& Accessory Stores

Eating \& Drinking Places 


\section{Detailed Bureau of the Census (BOC) Industry Groupings (cont'd) ${ }^{*}$}

BOC Industry Codes ${ }^{\dagger}$

580-600, 631-640, 642-691 (580-600, $632-640,642-691)$

700-710

$711-712$

761

$721-741(721-742)$

$742-760(750-760)$

$762-791$

$800-810(800-802)$

831

$812-830,832-840$

$842-860$

$841,861-893$ (861-892)

910

922

932

900-901, 921, 930-931
Industry Description

Other Retail Trade

Banking and Other Finance

Insurance and Real Estate

Private Household Services

Business Services

Automobile and Repair Services

Pers Serv Exc Priv Household

Entertainment \& Rec Services

Hospitals

Health Services, Exc Hosp

Educational Services

Other Professional Services

Justice, Pub Order, \& Safety

Admin of Hum Res Programs

National Sec/Internal Affairs

Other Pub Admin

• 1980 and 1990 Bureau of the Census Alphabetical Index.

${ }^{t}$ Code groupings were, for the most part, identical for the 1980 and $1990 \mathrm{BOC}$ industry codes.

Where differences do occur, the 1980 code groupings are provided in parentheses. 


\section{Appendix III}

\section{Detailed Bureau of the Census (BOC) Occupation Groupings*}

\section{BOC Occupation Codes ${ }^{\dagger}$}

003-006

007-022 (007-019)

023-037

043-063

064-068

069-083

084-089

095-106

$113-154$

155-159

$178-179$

163-177, 183-199

203-208

213-225

226-235

243

253-257

258-259

263-278

283-285

303-307

308-309

313-315

$337-344$

354-357

$316-336,345-353,359-389$

403-407

413-427

$433-444$

$445-447$

448-455

456-469

$473-476$

477-489

494-499

503-549

553-599

613-699
Occupation Description

Officials \& Administrators, Public Admin

Other Executive, Admin \& Managerial

Management Related Occupations

Engineers

Mathematical and Computer Scientists

Natural Scientists

Health Diagnosing Occupations

Health Assessment and Treatment Occupations

Teachers, College and University

Teachers, Except College and University

Lawyers and Judges

Other Professional Specialty Occupations

Health Technologists and Technicians

Engineering and Science Technicians

Technicians, Exc Health/Engineering/Science

Supervisors and Proprietors, Sales Occ

Sales Reps, Finance and Business Services

Sales Reps, Commodities, Except Retail

Sales Workers, Retail \& Personal Services

Sales Related Occupations

Supervisors, Administrative Support

Computer Equipment Operators

Secretaries, Stenographers, and Typists

Financial Records Processing

Mail and Message Distribution

Other Admin. Support, Including Clerical

Private Household Service Occupations

Protective Service

Food Service

Health Service

Cleaning and Building Service

Personal Service

Farm Operators and Managers

Farm Workers and Related Occupations

Forestry and Fishing Occupations

Mechanics and Repairers

Construction Trades

Other Precision Production, Craft, and Repair 


\section{Detailed Bureau of the Census (BOC) Occupation Groupings (cont'd)*}

BOC Occupation Codes ${ }^{\dagger}$

703-779

783-799

803-814

823-859

869

$875-883$

$864-868,874,885-889(863-867$, $873,885-889)$

\section{Occupation Description}

Machine Operators/Tenders, Except Precision Fabricators, Assemblers, Inspectors, Samplers Motor Vehicle Operators

Other Transport and Material Moving Occ Construction Laborers

Freight, Stock, \& Materials Handlers

Other Handlers, Equip. Cleaner, Helper, Laborer

• 1980 and 1990 Bureau of the Census Alphabetical Index.

${ }^{\dagger}$ Code groupings were, for the most part, identical for the 1980 and $1990 \mathrm{BOC}$ occupation codes.

Where differences do occur, the 1980 code groupings are provided in parentheses. 


\section{Appendix IV}

\section{ICD-9* E-code Rubrics for Cause of Death Categories}

\begin{tabular}{ll} 
Category & ICD-9 Rubric \\
\hline & \\
RailTransport & E800-E807 \\
MotorVehicle & E810-E829, E846-E849 \\
Water Transport & E830-E838 \\
AirTransport & E840-E845 \\
Poisoning & E850-E858, E860-E869 \\
Falls & E880-E888 \\
Fires & E890-E899 \\
Nature/Environment & E900-E909, E928 \\
Drowning & E910 \\
Suffocation & E911-E913 \\
StruckByFalling Object & E916 \\
FlyingObject/CaughtIn & E917, E918 \\
Machine & E919 \\
Explosion & E921, E923 \\
Electrocution & E925 \\
Suicide & E950-E959 \\
Homicide & E960-E969 \\
Other & E870-E879, E914, E915, E920, \\
& E922, E924, E926, E927, E929, \\
Unknown/Undetermined & E930-E949, E970-E978, E990-E999 \\
International Classification of Diseases, Ninth Revision.
\end{tabular}





\section{Appendix V}

Operational Guidelines for Determination of Injury at Work 


\section{Operational Guidelines For Determination Of Injury At Work}

1. Complete the injury at work item if any other than natural cause of death is mentioned in Part I or Part II of the medical certification, including homicides, suicides, and accidents, including motor vehicle deaths.

2. The injury at work item must be completed for decedents ages 14 or over and may be completed for those less than 14 years of age if warranted. Consider possibility of work injury regardless of whether injury occurred in the course of work in "usual" or other occupation and/or industry. If decedent's "usual" occupation is housewife, student, or retired consider possible injury during other employment. If occupation is transportation-related, suspect injury at work and evaluate per criteria.

3. Consider available information with regard to location and activity at time of injury. If location is farm, suspect work-related and evaluate per criteria.

\section{CRITERIA}

INJURY

AT WORK

\section{On Employer Premises}

- Engaged in work activity, apprentice, vocational training

- On break, in hallways, rest room, cafeteria, storage area

- In employer parkinglots while working, arriving, or leaving

- Engaged in recreational activities on employer controlled facilities (games, etc.) for personal enjoyment

- As a visitor for non-work purposes, not on official business

\section{Off Employer Premises}

- Working for pay or compensation, including at home

- Working as a volunteerEMS, firefighter, or law enforcement officer

- Working in a familybusiness, including family farm. Activity should be clearly related to a profit-oriented business.

- Traveling on business, including to and from customer/business contacts

- Engaged in work activity where vehicle is considered the work environment(e.g., taxi driver, truck driver, etc.)

- Homemakerworking athomemaking activities

- Working for self - non profit, i.e., mowing lawn, repairing own roof, hobby, or recreation activities

- Studentengaged in school activities

- Operating vehicle (personal or commercial)fornon-work purposes

- Commuting to or from work site

These guidelines were developed jointly by: The Association for Vital Records and Health Statistics (AVRHS), the National Institute for Occupational Safety and Health (NIOSH), the National Center for Health Statistics, (NCHS), and the National Center for Environmental Health and Injury Control (NCEHIC). 



\section{Appendix VI}

\section{Additional Readings}

Bell CA [1991]. Female homicides in United States workplaces, 1980-1985. Am J Public Health 81(6):729-732.

Biddle EA, Hartley D [2000]. Fire- and flame-related occupational fatalities in the United States, 1980-1994. J Occup Environ Med 42(4):430-437.

Bobick TG, Jenkins EL [1992]. Agricultural-related fatalities: 1986-1988. Advances in Industrial Ergonomics and Safety IV. Edited by S. Kumar, Taylor \& Francis (book chapter).

Braddee RW, Myers JR [1997]. Logging-type fatalities in the U.S. production agriculture industry, 1980-1992. J of Agromedicine 4(3/4):373-375.

Braddee RW, Pratt SG, Hause, M [1997]. Preventing falls from elevations. Welding Journal Special Report, Staying Safe on the Job 23-25.

Castillo DN, Landen DL, Layne LA [1994]. Occupational injury deaths of 16- and 17-year olds in the United States. Am J Public Health 84:646-649.

Castillo DN, Jenkins EL [1994]. Industries and occupations at high risk for work-related homicide. J Occup Med 36:125-132.

Castillo DN, Malit BD [1997]. Occupational injury deaths of 16- and 17-year olds in the United States: Trends and comparisons to older workers. Inj Prev 3:277-281.

CDC [1994]. Occupational injury deaths of postal workers-United States, 1980-1989. MMWR 43:587-595.

CDC [1996]. Skid-steer loader-related fatalities in the workplace-United States, 1992-1995. MMWR 45(29):624-628.

CDC [1998]. Fatal occupational injuries-United States, 1980-1994. MMWR 47(15):297-302.

CDC [1999]. Achievements in public health, improvements in workplace safety-United States, 1900-1999. MMWR 48(22):461-469.

Chen G-X, Fosbroke DE [1998]. Work-related fatal-injury risk of construction workers by occupation and cause of death. Human and Ecological Risk Assessment 4(6):1371-1390.

Collins JW, Landen DD, Kisner SM, Johnston JJ, Chin SF, Kennedy RD [1999]. Fatal occupational injuries associated with forklifts, United States, 1980-1994. Am J Ind Med 36:504-512. 
Etherton JR, Myers, JR Jensen RC, Russell JC, Braddee RW [1991]. Agricultural machine-related deaths. Am J Public Health 81(6):766-768.

Fosbroke DE, Kisner SM, Myers Jr [1997]. Working lifetime risk of occupational fatal injury. Am $\mathrm{J}$ Ind Med 31:459-467.

Goodman RA, Jenkins EL, Mercy JA [1994]. Work-related homicide among health care workers in the United States, 1980 through 1990. JAMA 272(21):1686-1688.

Hard DL, Myers JR, Snyder KA, Casini VJ, Cianfrocco R, Fields J, Morton L [1999]. Young workers at risk when working in agricultural production. Am J Ind Med, Supplement 1:31-33.

Hard DL, Myers JR, Snyder KA, Casini VJ, Morton LL, Cianfrocco R, Fields J [1999]. Identifying work-related fatalities in the agricultural production sector using two national occupational fatality surveillance systems, 1990-1995. J Ag Safety and Health 5(2):155-169.

Hodous TK, Layne LA [1993]. Injuries in the mining industry. In: Occupational Medicine, State of the Art Reviews. Occ Med 8(1):171-184.

Jenkins EL, Hard DL [1992]. Implications for the use of e-codes of the international classification of diseases and narrative data in identifying tractor-related deaths in agriculture, United States, 1980-1986. Scand J Work Environ Health 18 Suppl 2:49-50.

Jenkins EL, Layne LA, Kisner SM [1992]. Homicide in the workplace: The U.S. experience, 19801988. AAOHN J 40(5):215-218.

Jenkins EL [1996]. Homicide against women in the workplace. J Am Med Womens Assoc 51(3):118-122.

Jenkins EL [1996]. Workplace homicide: Industries and occupations at high risk. In: Occupational Medicine, State of the Art Reviews. Occ Med 11(2):219-224.

Kisner SM, Fosbroke DE [1994]. Injury hazards in the construction industry. J Occup Med $36(2): 137-143$.

Kisner SM, Pratt SG [1997]. Occupational fatalities among older workers in the United States: 1980-1991. J Occup Environ Med 39(8):715-721.

Kisner SM, Pratt SG [1999]. Occupational injury fatalities among older workers in the United States, 1980-1994. Am J Ind Med Supplement 1:24-25.

Moore PH, Pratt SG [1997]. Skid-steer loading machine-related deaths and prevention strategies. Presented and published in the proceedings of the 1997 Summer Conference, National Institute for Farm Safety, Inc., Indianapolis, IN, June 22-26, 1997. NIFS Technical Paper 97-8.

Myers JR [1990]. National surveillance of occupational fatalities in agriculture. Am J Ind Med 18:163-168. 
Myers JR, Fosbroke DE [1994]. Logging fatalities in the United States by region, cause of death, and other factors-1980 through 1988. J Safety Res 25(2):97-105.

Myers JR, Hard DL [1995]. Work-related fatalities in the agricultural production and services sectors, 1980-1989. Am J Ind Med 27:51-63.

Myers JR, Hard DL, Snyder KA, Casini VC, Cianfrocco R, Fields J, Morton L [1998]. Statistics and epidemiology of tractor fatalities-A historical perspective. J Ag Safety and Health 4(2):95-108.

Myers JR, Hard DL, Snyder KA, Casini VJ, Cianfrocco R, Fields J, Morton L [1999]. Risks of fatal injuries to farm workers 55-years of age and older. Am J Ind Med, Supplement 1:29-30.

NIOSH [1989]. National traumatic occupational fatalities: 1980-1985. DHHS (NIOSH) Pub. No. $89-116$.

NIOSH [1993]. NIOSH Alert: Preventing homicides in the workplace. DHHS (NIOSH) Pub. No.93-109.

NIOSH [1994]. Worker deaths in confined spaces: A summary of NIOSH surveillance and investigative findings. DHHS (NIOSH) Pub. No. 94-103.

NIOSH [1995]. NIOSH Alert: Request for assistance in preventing injuries and deaths of adolescent workers. DHHS (NIOSH) Pub. No. 95-125.

NIOSH [1996]. NIOSH Current Intelligence Bulletin: Violence in the workplace risk factors and prevention strategies. DHHS (NIOSH) Pub. No. 96-100.

NIOSH [1998]. NIOSH Alert: Preventing worker injuries and deaths from traffic-related motor vehicle crashes. DHHS (NIOSH) Pub. No. 98-142.

NIOSH [1998]. Worker deaths by electrocution: A summary of surveillance findings and investigative reports. DHHS (NIOSH) Pub. No. 98-131.

NIOSH [2000]. Worker deaths by falls: A summary of surveillance findings and investigative case reports. DHHS (NIOSH) Pub. No. 2000-116.

Ore T, Casini V [1996]. Electrical fatalities among U.S. construction workers. J Occup Environ Med 38(6):587-592.

Ore T, Stout NA [1996]. Traumatic occupational fatalities in the U.S. and Australian construction industries. Am J Ind Med 30:202-206.

Ore T, Fosbroke DE [1997]. Motor vehicle fatalities in the United States construction industry. Acc Anal Prev 29(5):613-626.

Ore T, Stout NA [1997]. Risk differences in fatal occupational injuries among construction laborers in the United States, 1980-1992. J Occup Environ Med 39(9):832-843. 
Pratt SG, Kisner SM, Helmkamp JC [1996]. Machinery-related occupational fatalities in the United States, 1980 to 1989. J Occup Environ Med 38(1):70-76.

Pratt SG, Kisner SM, Moore PH [1997]. Machinery-related fatalities in the construction industry. Am J Ind Med 32:42-50.

Robinson CF, Halperin WE, Alterman T, Braddee RW, et al [1995]. Mortality patterns among construction workers in the United States. In: Occupational Medicine, State of the Art Reviews. Occ Med 10(2):269-283.

Schnitzer PG, Landen DD, Russell JC [1993]. Occupational injury deaths in Alaska's fishing industry, 1980. Am J Public Health 83(5):685-688.

Snyder KA, Bobick TG, Hanz JL, Myers JR [1992]. Grain-handling fatalities in production agriculture, 1985-1989. In: American Society of Agricultural Engineers 1992 International Winter Meeting, December 15-18, 1992, Nashville, TN. Paper No. 92-5509.

Sorock GS, Smith GS, Reeve GR, Dement J, Stout N, Layne L, Pastula ST [1997]. Three perspectives on work-related injury surveillance systems. Am J Ind Med 32:116-128.

Stout NA, Jenkins EL, Pizatella TJ [1996]. Occupational injury mortality rates in the United States: Changes from 1980-1989. Am J Public Health 86(1):73-77.

Sugarman JR, Stout N, Layne LA [1993]. Traumatic occupational fatalities among American Indians and Alaska Natives, 1980-1988. J Occup Med 35:1111-1122.

Suruda A, Smith L [1993]. Work-related electrocutions involving portable power tools and appliances. J Occup Med 34(9):887-892.

Suruda A, Fosbroke D, Braddee R [1995]. Fatal work-related falls from roof. J Safety Res 26(1):1-8. 



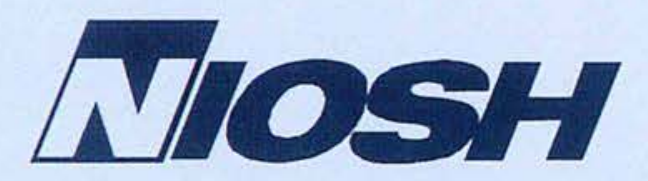

Delivering on the Nation's Promise:

Safety and health at work

$$
\text { For all people }
$$

Through research and prevention

To receive other information about occupational safety and health topics, call 1-800-35-NIOSH (1-800-356-4674), or visit the NIOSH Website at: www.cdc.gov/niosh 